\title{
Sacred myths: archaeology and authenticity
}

\author{
Book or Report Section
}

Published Version

Creative Commons: Attribution-Noncommercial-No Derivative Works 4.0

Open access

Gilchrist, R. (2020) Sacred myths: archaeology and authenticity. In: Gilchrist, R. Sacred Heritage: Monastic Archaeology, Identities, Beliefs. Cambridge University Press, Cambridge, pp. 176-218. ISBN 9781108678087 doi: https://doi.org/10.1017/9781108678087.007 Available at https://centaur.reading.ac.uk/88525/

It is advisable to refer to the publisher's version if you intend to cite from the work. See Guidance on citing.

To link to this article DOI: http://dx.doi.org/10.1017/9781108678087.007

Publisher: Cambridge University Press

Publisher statement: An online version of this work is published at doi.org/10.1017/9781108678087 under a Creative Commons Open Access license CC-BY-NC-ND 4.0 which permits re-use, distribution and reproduction in any medium for non-commercial purposes providing appropriate credit to the original work is given. You may not distribute derivative works without permission. To view a copy of this license, visit https://creativecommons.org/licenses/by-nc$\mathrm{nd} / 4.0$. All versions of this work may contain content reproduced under license from third parties. Permission to reproduce this third-party content must be obtained from these third-parties directly.

All outputs in CentAUR are protected by Intellectual Property Rights law, including copyright law. Copyright and IPR is retained by the creators or other copyright holders. Terms and conditions for use of this material are defined in 
the End User Agreement.

www.reading.ac.uk/centaur

\section{CentAUR}

Central Archive at the University of Reading

Reading's research outputs online 


\section{$\operatorname{SIX}$}

\section{SACRED MYTHS: ARCHAEOLOGY AND AUTHENTICITY}

\section{INTRODUCTION: SAINTS, SCHOLARS AND KINGS}

This final chapter examines the role of archaeology in authenticating or challenging modern myths connected with medieval sacred sites. Sacred heritage sites are closely connected to nationalist narratives, both in the Middle Ages and today, for example through origin myths, the stories of saints and their martyrdom, military heroes and dynastic battles. Monasteries were centres of both religious and royal power, often serving as the burial place for saints and kings. It was common for medieval religious use to be just one phase of a longer-lived sacred landscape - certain places attracted a genuine continuity of ritual practice, while others were subject to the later 'invention' of sacred tradition, in order to legitimate a religious or political narrative (Shaw 2013b, after Hobsbawm I983). My aim in this concluding chapter is threefold: first, to consider how medieval sacred heritage is used to construct myths connected with nationalist and religious identities; second, to review the role of archaeology in authenticating or challenging sacred myths; and third, to reflect on medieval sacred landscapes as contested heritage sites which hold multiple meanings to contemporary social groups. How have archaeologists contributed to the construction of myths at medieval sacred sites? In what ways have archaeology and material culture been used to authenticate religious narratives? What are the dominant and alternative myths that operate at sacred heritage sites, and what are the tensions between them? I will begin with some brief definitions of 'authenticity' and 'myth'. 
Authenticity has been thoroughly explored in the heritage literature and remains a core principle for assigning heritage 'value'. Keith Emerick has commented that 'authenticity is an intellectual dead end' (Emerick 20I4: 7); he argues that the 'sacred cows of conservation' - antiquity, fabric and authenticity - have outlived their usefulness and need to be rethought as we move towards more democratic heritage practices. He encourages heritage practitioners to focus instead on the relationship between people, story and place (Emerick 20I4: 2I6). However, his critique is aimed at the traditional definition of authenticity as a construct of value defined by archaeological professionals, based on judgements of the quality of material evidence. It is now widely understood that authenticity is culturally constructed and varies between social groups and cultural contexts, following the wide definition of authenticity as set out in the Nara Document on Authenticity (ICOMOS I994) as: 'that which embodies the cultural heritage values of the place'. Recognition of intangible heritage was an important factor in these debates: the oral traditions, myths, performing arts, rituals, knowledge and skills that are transmitted between generations to provide communities with a sense of identity and continuity (ICOMOS I994; UNESCO 2003). Acknowledgement of intangible heritage has heightened awareness that concepts of authenticity are culturally relative; while European traditions of authenticity privilege fabric and antiquity, other traditions may emphasise people and spirit (Jones 20IO).

European approaches to authenticity can be broadly divided into materialist and constructivist perspectives, the latter acknowledging that authenticity varies according to social and cultural contexts (Holtorf 20I3a). Siân Jones has explored the constructivist concept of authenticity in relation to intangible heritage, which includes spiritual beliefs and related practices, artefacts and spaces. Jones focuses her discussion on the Hilton of Cadboll cross-slab, a Pictish sculpture dating to c.80o CE (Easter Ross, northeast Scotland) (Jones 20IO). She reveals the strong local attachment to the object and the shared sentiment that it is a living thing - a member of the community - and integral to the local landscape and sense of place. Removal of the slab from its original setting created tensions between the local community and national heritage agencies, demonstrating how local voices may conflict with heritage managers and lead to the rejection of professional authority. Jones concludes that authenticity is not about the status of objects in themselves, but rather about the social relationships between people and things, 'a means for people to negotiate their own place' in a complex world (Jones 20I0: 197). She emphasises the importance of the cultural biographies of objects - their life histories in discussions of their authenticity. Cornelius Holtorf has responded to Jones by calling for constructivist approaches that reinstate the importance of materiality to authenticity, particularly how people respond perceptibly to the material qualities of objects in perceiving their 'pastness' (Holtorf 20I3a). My 
aim in this chapter is to consider how authenticity is constructed in relation to sacred heritage: how do the spiritual credentials of a place relate to understandings of its materiality and historicity?

The term 'myth' is often used pejoratively, implying a false story or superstitious belief. Archaeologists in Britain have been wary of engaging with myth and folklore, even when investigating sites steeped in legend, such as the hillfort of Cadbury Castle (Somerset), popularly known as Camelot, the court of King Arthur. The site was investigated in the I960s by the Camelot Research Committee, led by Leslie Alcock (Alcock 1972). The Arthur question dominated the project: Alcock rejected the site's folklore as romantic superstition, but he was firmly committed to the belief that he could tease out the historical 'facts' about Arthur as a genuine historical figure (Paphitis 2013: I5). More recently, the significance of myths to archaeological interpretation has been reasserted. In particular, archaeologists studying Celtic and Old Norse myths have emphasised the importance of reflecting critically on long-term continuities in belief. For example, Jim Mallory and John Waddell have explored the potential for using medieval Irish literature to discern elements of pre-Christian and Christian Celtic myth (Mallory 20I6; Waddell 20I4), while Anders Andrén and Lotte Hedeager have used Old Norse myths to explore beliefs prevalent in the Scandinavian Iron Age (Andrén 20I4; Hedeager 20II).

The psychological basis of ancient myths has also been considered: Jordan B. Peterson examines myths from the perspective of neuropsychology, describing them as 'maps of meaning'. He argues that similar structures of storytelling have developed cross-culturally to explain human existence in terms of archetypes, enabling us to deal with the unknown and to defend our familiar territory from external threats (Peterson 1999). Religious scholars employ the term myth more neutrally, to describe a significant story, making no value judgements about its truth or veracity. Myths are seen as an ongoing narrative, the process of story-telling as a constantly evolving feature of religion (Bowman 2000: 85). Myths are integral to sacred narratives, representing our relationship with ancestors, the supernatural and the natural world. According to Roland Barthes, myth 'transforms history into nature' (Barthes I994: I29), and for Jaan Puhvel, myth brings the sacred past to bear on the present and the future (Puhvel 1987: 2). I am particularly concerned here with 'origin' myths and how they relate to medieval sacred sites and the nationalist and religious narratives associated with them - what we might term 'Golden Age' stories.

THE 'GOLDEN AGE': AUTHENTICITY AND NATIONALIST NARRATIVES

The reciprocal relationship between archaeological practice and nation states was highlighted by Bruce Trigger over thirty years ago (Trigger 1984). He 
demonstrated that archaeology could serve alternative interpretations of the past, depending on whether the state concerned is nationalist, imperialist or colonialist in outlook. Subsequent work has emphasised the socio-political context of archaeology and how archaeological approaches and practices may lend themselves to nationalist arguments (Díaz-Andreu and Champion I996; Habu, Fawcett and Matsunaga 2008). Nationalism seeks refuge in archaeology's emphasis on continuity and the rootedness of material traditions to particular places, territories and ethnic groups. Above all, archaeologists and nationalists share a 'profound concern with the authenticity of material culture' (Smith 200I: 44I), resulting in archaeology's vulnerability to appropriation by right-wing groups who are drawn to 'Golden Age' narratives. Nationalist narratives look particularly to sacred sites to embody the 'Golden Age' when a nation was most heroic and authentically itself, before what may be perceived as later accretions caused by religious conversion, military conquest or mass migration (Smith 200I: 445). To give a contemporary example, far-right political parties in Scandinavia are promoting heritage in their attempts to combat the current forces of globalisation and non-Western immigration, with particular focus on Christian heritage (Niklasson and Hølleland 20I8: I26). Recent shifts in global politics, in the UK including uncertainties around Brexit and Scottish independence, have once again highlighted the urgency of these questions for archaeologists. There is a renewed concern to understand the relationship between archaeology and nationalism and how this intersects with questions of identity, the study of migration and the practice and funding of archaeology (Brück and Nilsson Stutz 20I6).

The most powerful evocations of nationhood bring together religious and secular power, for example landscapes of sacral kingship such as Tara, the traditional seat of the kings of Ireland, and Gamla Uppsala in Sweden, the burial place of kings and the cult centre of Old Norse religion (Bhreathnach 2005; Ljungkvist and Frölund 20I5). Archaeologists were active in forging nationalist connections with monuments and landscapes in the eighteenth and nineteenth centuries, but nationalist myths have continued to interact with archaeological scholarship in the twentieth and twenty-first centuries. This process is particularly clear in the emergence of Irish archaeology around the Celtic 'Golden Age' narrative and its continued relevance in shaping research to the present day (O'Sullivan 1998). The central figure in this movement was George Petrie (I790-I866), the founder of scientific archaeology in Ireland but also a leading proponent of Celtic nationalism. His aim was to bring together Catholics and Protestants in a common love of their shared descent from the ancient Celts (Cooney I996: I5I-5; Hutchinson 200I: 506). Petrie collected objects for the Royal Irish Academy such as the Tara Brooch and the Armagh Chalice, both dated to the eighth century CE, and he worked with landscape artists to promote early medieval monastic landscapes 
such as Clonmacnoise (Offaly). His archaeological scholarship presented a new image of Celtic Ireland based on the Christian period of the eighth to eleventh century, before this (allegedly) utopian Celtic culture was shattered by AngloNorman invasion (Hutchinson 200I: 508). Christian artefacts were widely adopted as symbols of Celtic heritage in Irish architecture, arts and crafts and popular culture (Sheehy I980). Far from uniting the sectarian divide, however, both Catholics and Protestants employed Early Christian archaeology to authenticate their own narratives. For Catholics, archaeology confirmed a vision of the sacred Celtic past, brutally undermined by the barbaric Normans; for Protestants, archaeology revealed the pristine Christianity of the Celts, before the corruption of Roman Catholicism in the twelfth century (Hutchinson 200I: 5I3). The 'Golden Age' narrative continued to impact on the development of medieval archaeology in Ireland throughout the twentieth century, by privileging the study of Irish ecclesiastical sites of the early medieval period over those of the later medieval period (O'Sullivan I998; O'Sullivan et al. 20I4).

Archaeologists in Britain were less overtly political in their use of medieval sacred sites and material culture, reflecting their cultural inheritance as the colonisers rather than the colonised. However, they were no less active in promoting 'Golden Age' narratives. For example, the renowned Egyptologist Margaret Murray drew on the evidence of sculptural carvings in medieval churches in Britain to argue that paganism had survived into the Middle Ages and subsisted harmoniously alongside Christianity (Hutton 20I4: 347). She was the first to suggest that sheela-na-gigs, carved female figures exposing their genitalia, were icons of ancient fertility goddesses that continued to be worshipped by medieval people (Murray I934). Around the same time, Julia (Lady) Raglan argued that the foliate carved heads common in medieval English churches were 'green men' and that they represented the persistent survival into the Middle Ages of a pagan fertility god (Raglan 1939). These interpretations were accepted for decades, before historians in the I970s challenged the pagan reading of medieval church images and other sources of evidence. Despite scholarly critiques, these interpretations continue to inform modern Pagan Wicca beliefs, while sheela-na-gigs have been adopted as a feminist symbol and green men are a popular icon for the environmentalist movement (Hutton 20I4: 347-5I).

Following the Second World War, medieval archaeologists actively promoted British (Celtic) national heritage as distinct from Anglo-Saxon (Germanic) heritage. This is reflected in the popular search for Arthur, as demonstrated by the work of the Camelot Research Committee at Cadbury Castle (Alcock 1972; Paphitis 20I3). Nationalist myths were connected to sacred sites such as Whithorn (Dumfries and Galloway) and Glastonbury (Somerset), where archaeological research agendas were shaped by Celtic 


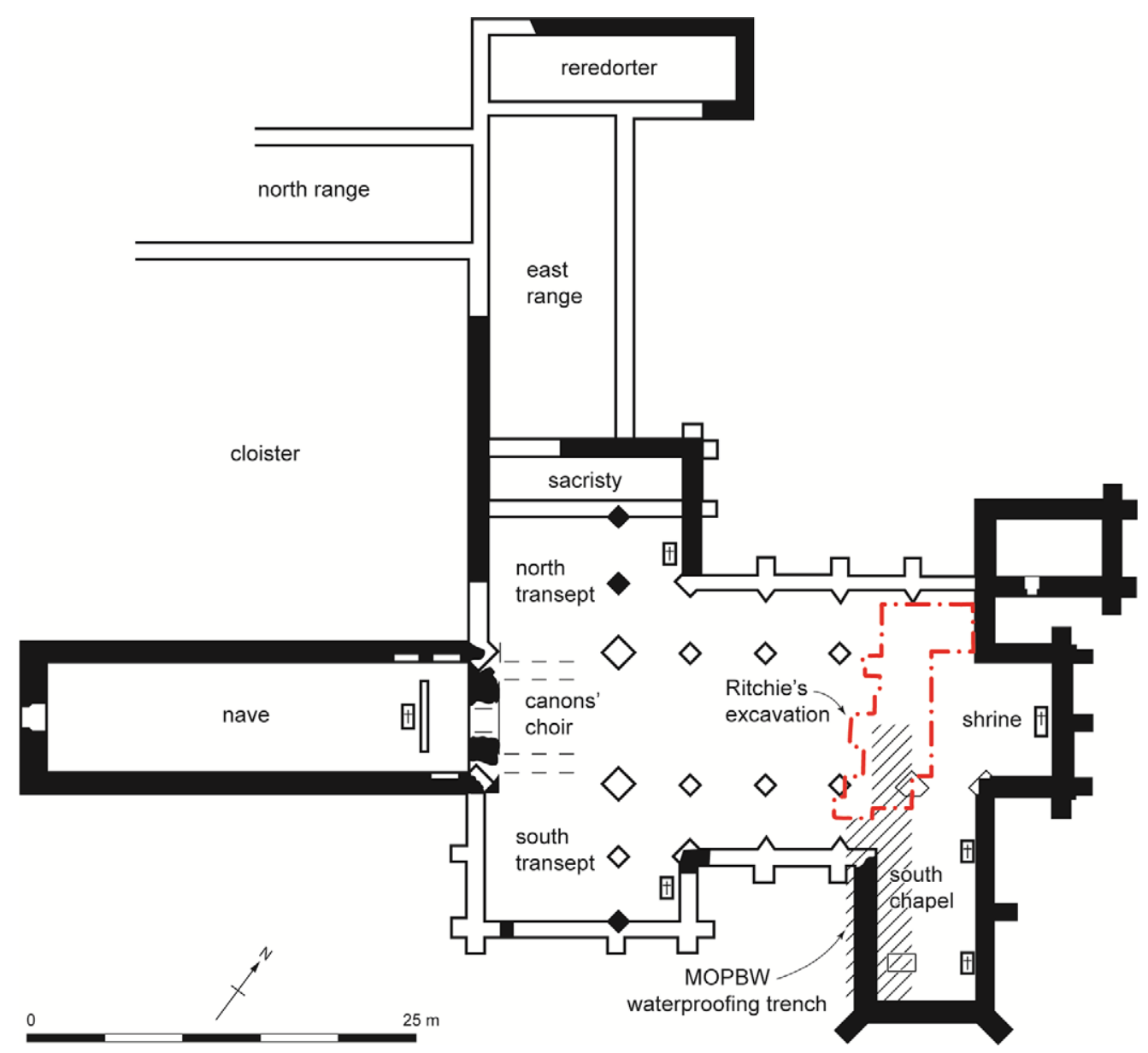

6. I Plan of Whithorn Priory (Dumfries and Galloway). C Headland Archaeology (UK) Ltd

hagiography and narratives. Both sites are promoted as 'the cradle of Christianity', in Scotland and England respectively. St Ninian was first documented by Bede, c.73I, and he is popularly regarded as having founded Whithorn (Candida Casa) in the early fifth century. Glastonbury's claim to religious primacy is based on the legend of the 'old church' (vetusta ecclesia) first recorded in the tenth century, and by the fourteenth century regarded as the earliest church in Britain, believed to have been founded by Joseph of Arimathea in the first century CE (see Chapter 5 for discussion). The sacred narratives attached to these sites have frequently clouded interpretations of the archaeological evidence.

From 1957-67, Roy Ritchie excavated a series of graves near the high altar of the cathedral church at Whithorn (discussed in Chapter 4) (Figures 6.I and 6.2). The leading church archaeologists of the day assembled at Whithorn to pronounce their views on the sequence - Stewart Cruden, Ralegh Radford and Charles Thomas. They believed that the graves spanned a period of I,000 


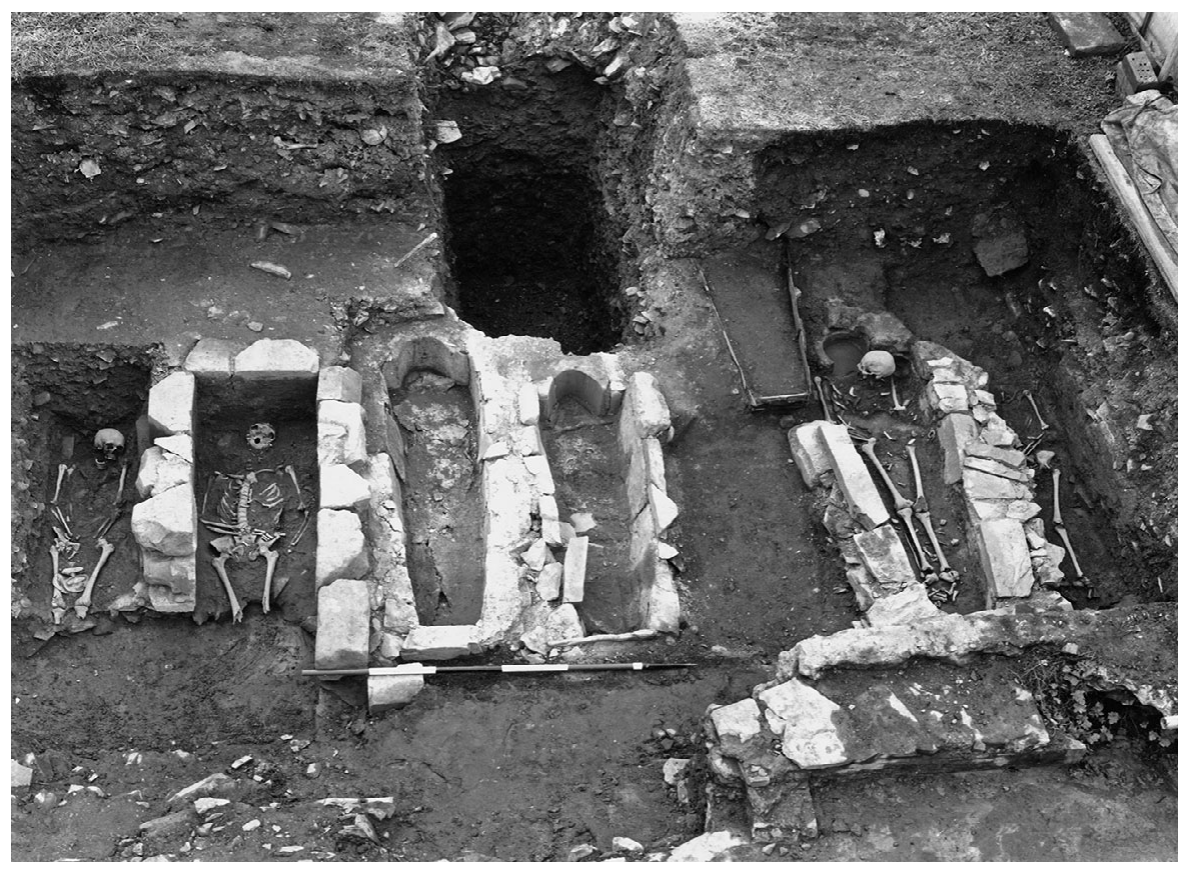

6.2 Photograph of burials during excavation of Whithorn Priory (Dumfries and Galloway).

(C) Crown Copyright: Historic Environment Scotland

years, connecting St Ninian's Candida Casa with the late medieval cathedral priory at Whithorn. They published interim statements claiming a late Roman cremation cemetery as well as Early Christian burials (Thomas I97I: 55). In his reassessment of Ritchie's excavations, Christopher Lowe describes their collective views as a 'suite of unsubstantiated claims relating to the origins of the site'. He suggests that Ritchie's failure to publish the excavations may have been caused by his inability to reconcile the archaeological evidence with the claims made by these very senior and influential figures (Lowe 2009: I77, I67). Fresh analysis and radiocarbon dating confirms that the Whithorn graves span a period of only 400 years, beginning in the twelfth century. They have no bearing on our understanding of Whithorn's origins, or the story of St Ninian's foundation. Lowe concludes that the complete absence of first millennium material from Ritchie's excavations demands reassessment of the presumed relationship of the medieval cathedral priory with the preceding Northumbrian ecclesiastical settlement (Lowe 2009: I78).

The figure most closely associated with excavations at Glastonbury Abbey is Courtenay Arthur Ralegh Radford, who excavated at the site from I95I-64 (Figure 6.3). As well as his involvement with Glastonbury and Whithorn, he excavated at numerous sites in southwest England, Scotland, Ireland and the Isle of Man. Radford was a committed Christian, describing himself as 'High Anglo-Catholic'. His personal beliefs were reflected in his scholarship: he 


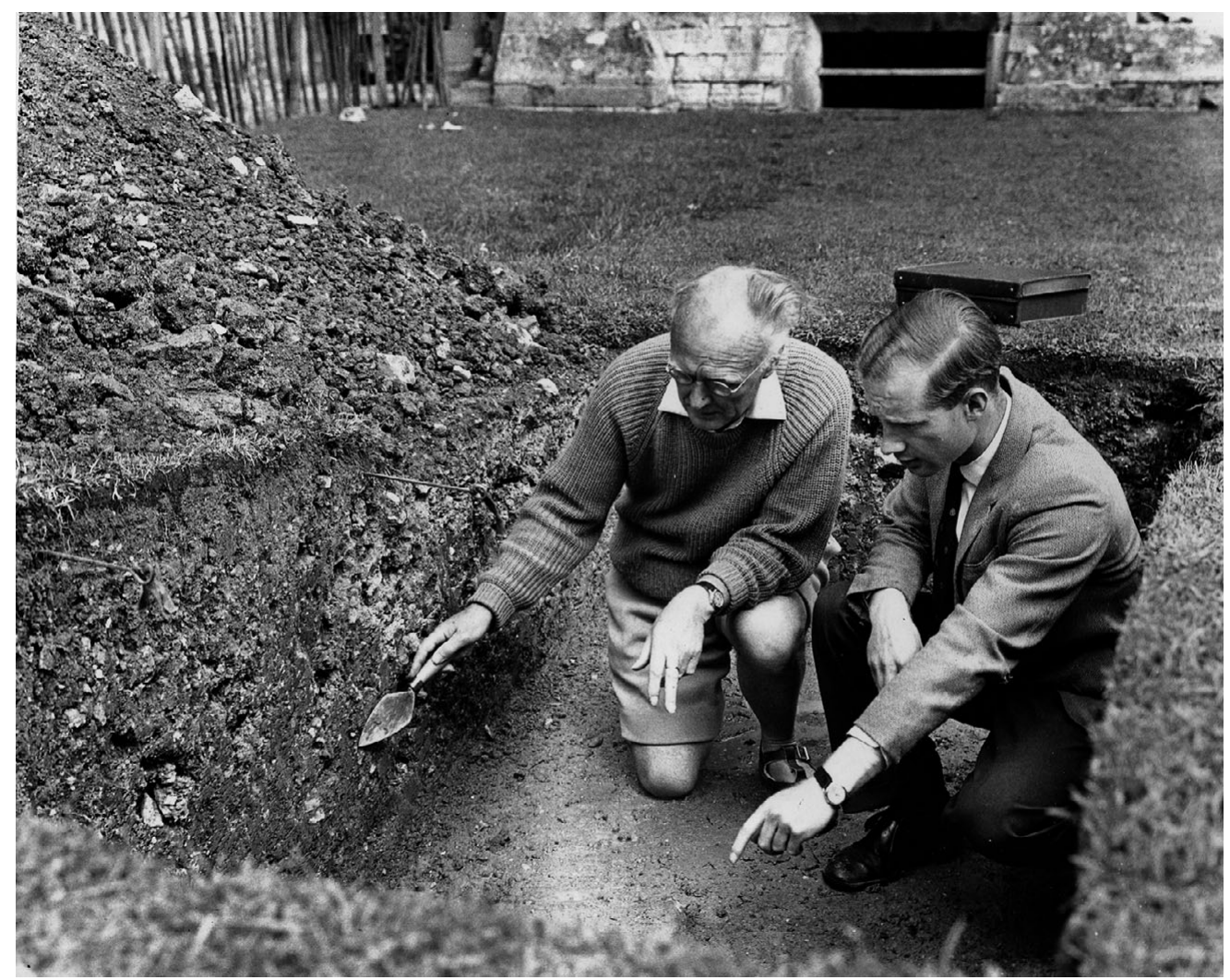

6.3 Courtenay Arthur Ralegh Radford (left) at Glastonbury Abbey (Somerset) in I962. Reproduced by kind permission of Peter Poyntz Wright

advocated the study of the post-Roman period as 'Early Christian archaeology' and he pioneered the study of Celtic monasticism in western Britain (Gilchrist 20I3). He was a strong proponent of Glastonbury's 'Golden Age', and presented the abbey's archaeology within a Celtic framework. He acknowledged that his excavations at the abbey had discovered virtually no evidence for a religious community earlier than the eighth century CE. This absence of evidence did not deter him: he described a Christian community at Glastonbury 'in Celtic times' and considered the abbey as one part of the 'holy city' of the Isle of Avalon (Radford I98I). He even ventured that Glastonbury was a pagan holy place of the ancient Celts, drawing on the tenuous evidence of early Irish saints mentioned in the abbey's later medieval chronicles (Radford I968).

Radford interpreted the archaeological sequence at Glastonbury within a framework defined by Celtic hagiography and legend. His Christian beliefs also affected his field practice - for example, he was opposed to the disturbance of Christian skeletons, a rare ethical stance in the I950s. After minimal recording, skeletons at Glastonbury were left in situ and covered over again 
with soil (Gilchrist and Green 2015: 425). Radford's site chronology was defined by historical references to individuals and events, in particular to St Dunstan (909-88 CE), the abbot who revived Glastonbury in the mid-tenth century and went on to reform English monasticism as archbishop of Canterbury. The twelfth-century historian William of Malmesbury recorded that St Dunstan had enclosed the cemetery and raised the ground level as part of his rebuilding of the abbey in the tenth century. Radford's excavations in the cemetery identified a layer of redeposited clay as the material that was laid down by Dunstan; he assigned a tenth-century date by virtue of the description in William of Malmesbury. Clay makeup layers in the cemetery were identified thereafter as a tenth-century horizon ('St Dunstan's clay'). Radford also interpreted structural remains through the prism of the tenth-century Life of Dunstan (dated c.955).

Glastonbury flourished under Dunstan, who substantially rebuilt and reformed the monastery. According to the vita, he 'first surrounded the cloisters on every side with solid monastery buildings' and enclosed the monks' cemetery with a stone wall (Winterbottom and Lapidge 2012: 50-I). Radford found structural evidence that could be dated to the late Saxon period - but his interpretation of the archaeology was shaped by his desire to locate Dunstan's cloister. He claimed to have found evidence for the earliest cloister in England, represented by narrow claustral ranges surrounding a courtyard measuring $55 \mathrm{~m}$ by $36 \mathrm{~m}$ (Figure 6.4). This evidence has been widely accepted and repeated as confirmation of the influence of Dunstan and the importance of Glastonbury in reforming the character of English monasticism in the tenth century (e.g. Fernie 1983: 85-6). Traces of the three claustral ranges were uncovered during separate excavation campaigns in the I930s, the I950s and the I970s. Radford connected them on the basis of his personal memory of observed similarities in the masonry construction; there were no proven stratigraphic relationships and there is no evidence that they are all of the same date. When the excavated remains are mapped, it is clear that the eastern walls of the supposed eastern range are misaligned. There is no proof that the structures to the north and south of the refectory were connected or that the junction of two rooms to the south of the refectory represents the meeting of a south and east range. The archaeological evidence is insufficient to reconstruct a full cloister as envisaged by Radford (Gilchrist and Green 2015: 394-5).

Instead, it appears that several free-standing masonry structures were located across the area of the later west cloister, south of the refectory, and possibly below the later abbot's hall. The buildings in the area of the later west cloister and refectory are sealed by twelfth-century deposits and therefore may be late Saxon in date. However, the plan evidence based on recent study of the archaeological archive does not correspond with the cloister reconstructed by Radford. It is likely that his identification of a cloister relied heavily on the Life 


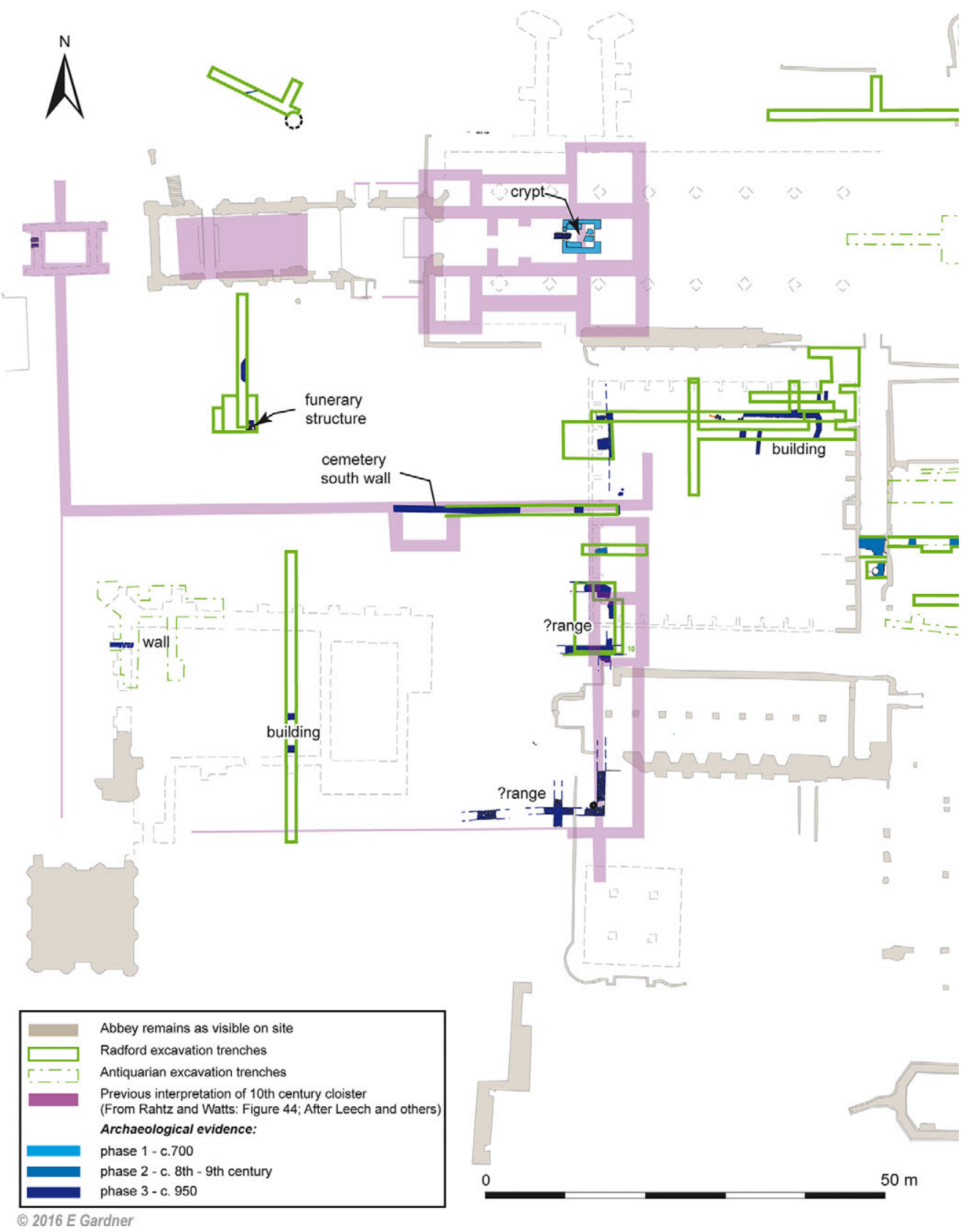

6.4 Plan showing archaeological evidence relating to Radford's Saxon 'cloister' at Glastonbury Abbey (Somerset) (C) Liz Gardner

of St Dunstan, which described Dunstan's devotion to the Rule of St Benedict and his building of a cloister. It is important to note that the Latin term claustrum can refer either to an enclosure or a formal cloister. On comparison with excavated monastic sites such as Jarrow (Cramp 2005), we know that 
free-standing stone ranges are more typical of accommodation at English monasteries right up to the late eleventh century. On the evidence available, it seems unlikely that Glastonbury possessed a formal cloister before the twelfth century (Gilchrist and Green 20I5: 420). Dunstan's cloister is a Christian 'Golden Age' story, one perpetuated by Radford and repeated by subsequent archaeologists and architectural historians.

Radford also projected the Celtic 'Golden Age' narrative onto Glastonbury. He regarded the post-Roman period in the southwest of Britain as a heroic age linked to the figure of King Arthur; he investigated a series of sites with Arthurian connections, including Glastonbury, Tintagel, Castle Dore and Cadbury Castle (Radford and Swanton 1975). In 1962-3, he deliberately searched for Arthur's grave at Glastonbury Abbey, using medieval accounts to identify the approximate location in the cemetery. He located a large pit and reported to the press that this was the exhumation site of II9I, where the monks of Glastonbury claimed to have found the remains of Arthur and Guinevere (Gransden 200I; see Chapter 5). He argued that the pit had been dug out and then shortly afterward refilled in the IIgos. The evidence for his precise dating was based on the presence of chippings of Doulting stone, which Radford assumed was first used at Glastonbury in rebuilding the Lady Chapel shortly after the great fire of II 84 . At the base of the pit were two cist graves that Radford believed to be sixth century in date. He claimed that the cist graves and the Doulting stone provided dating evidence for the supposed grave to be sixth century or later, and the exhumation event to be around II9O.

These dates matched the documented date of the alleged exhumation of Arthur by the monks in II9I, and the approximate date of the legendary king's death in the sixth century. In an interview with a local newspaper, Radford is quoted as saying 'I have always been one of the historians who believed Arthur to be an historical character and today I have added additional proof (The Western Morning News, I5 August 1963). His findings were widely reported and accepted as conclusive evidence by the media, who in the I960s displayed a touching confidence in the value of experts: 'to the untrained eye the discovery means nothing ... a patch of dark earth with a few stones protruding' (Central Somerset Gazette, I6 August I963). Recent reassessment of Radford's archaeological archive has challenged his dating evidence and refuted the identification of Arthur's grave (Gilchrist and Green 20I5: 394). The cist graves were cut into a layer of redeposited clay that was believed to be associated with levelling of the cemetery in the tenth century ('St Dunstan's clay'). In other words, the cist graves must be later than the clay, which is likely tenth century in date. Similar cists burials excavated at nearby Winchester Cathedral and Wells Cathedral have been dated to the later eleventh century (Rodwell 200I). Doulting stone is now recognised as the principal building material used in all phases of Glastonbury Abbey: Doulting has been identified among the 
Anglo-Saxon carved stone from the abbey and was certainly used before the rebuilding of the Lady Chapel in the last decade of the twelfth century. Pottery associated with the pit dates from the twelfth to the fifteenth century. Fresh analysis of the archaeological archive therefore confirms that the feature Radford located in 1963 was merely a refuse pit and not a robbed early grave.

At Glastonbury and Whithorn in the mid-twentieth century, archaeologists were concerned first and foremost to authenticate origin myths, the stories that connected sacred sites to a 'Golden Age' of Celtic saints and heroic kings. Today, the pendulum has swung full circle, with archaeologists more likely to argue that early monasteries had their origins in secular, royal settlements (e.g. Thomas 20I3). Excavations at Whithorn recovered a large quantity of imported, coloured glass from drinking vessels, perhaps more consistent with the consumption pattern of a secular site than a monastery (Forsyth and Maldonado 2OI3). Reassessment of the archive at Glastonbury Abbey revealed sherds of late Roman pottery (LRAI) confirming the presence of amphorae imported from the eastern Mediterranean carrying wine and oil, dated c.450-550 CE (Gilchrist and Green 2015: 4I6; see Chapter 5, Figure 5.4). The precise character of Glastonbury in the fifth or sixth century remains unclear, but it is possible that both Whithorn and Glastonbury originated as high status secular sites.

\section{AUTHENTICATING SACRED SITES: PRESERVATION, \\ REPLICATION AND THE PROOF OF ARCHAEOLOGY}

In addition to feeding nationalist narratives, archaeological evidence has been harnessed by faith communities to authenticate the spiritual authority of sacred sites. Religious communities were reinstated on the sites of ruined abbeys throughout Europe in the nineteenth century, for example as part of the 'religious revival' in France and Belgium after the trauma and destruction of the French Revolution (Coomans 20I2). Monasteries were also revived as an expression of regional identity; for instance, Landévennec Abbey was restored during the I920s and I930s by the Breton nationalist movement, as the symbol of historic Brittany (Tranvouez 20I5). Three British case studies are considered here: Glastonbury, Walsingham and Iona were all reinstated as sacred sites in the twentieth century, with archaeology, preservation and replication playing different roles in each case.

The village of Walsingham in Norfolk is known as 'England's Nazareth' (Janes and Waller 20IO). It was the site of a major medieval shrine to the Virgin Mary, second only to Canterbury as a destination for medieval pilgrimage in England (Marks 2004: 193-7). Souvenirs of Walsingham are amongst the most numerous examples of surviving medieval pilgrims' badges and ampullae, concentrated in East Anglia but distributed throughout Britain (Locker and Lewis 20I5). The cult was sparked by a vision of the Virgin Mary, who 
appeared in I06I to a wealthy Anglo-Saxon widow, Richelde de Faverches. The Virgin instructed Richelde to build a wooden replica of the House of the Annunciation, the site where Mary was visited by the Angel Gabriel, who brought news that she carried the Christ Child. The replica Holy House at Walsingham was believed to be modelled on the precise dimensions of the original in Nazareth, reproducing a biblical space in medieval Norfolk (Coleman 2004: 55). A statue of the Virgin was installed within it and an Augustinian priory was built on the site in II53 (Knowles and Hadcock I97I). There was also a Franciscan friary and a wayside chapel for pilgrims, known as the Slipper Chapel, located $2.4 \mathrm{~km}$ (I.5 miles) from the village (Figure 6.5).

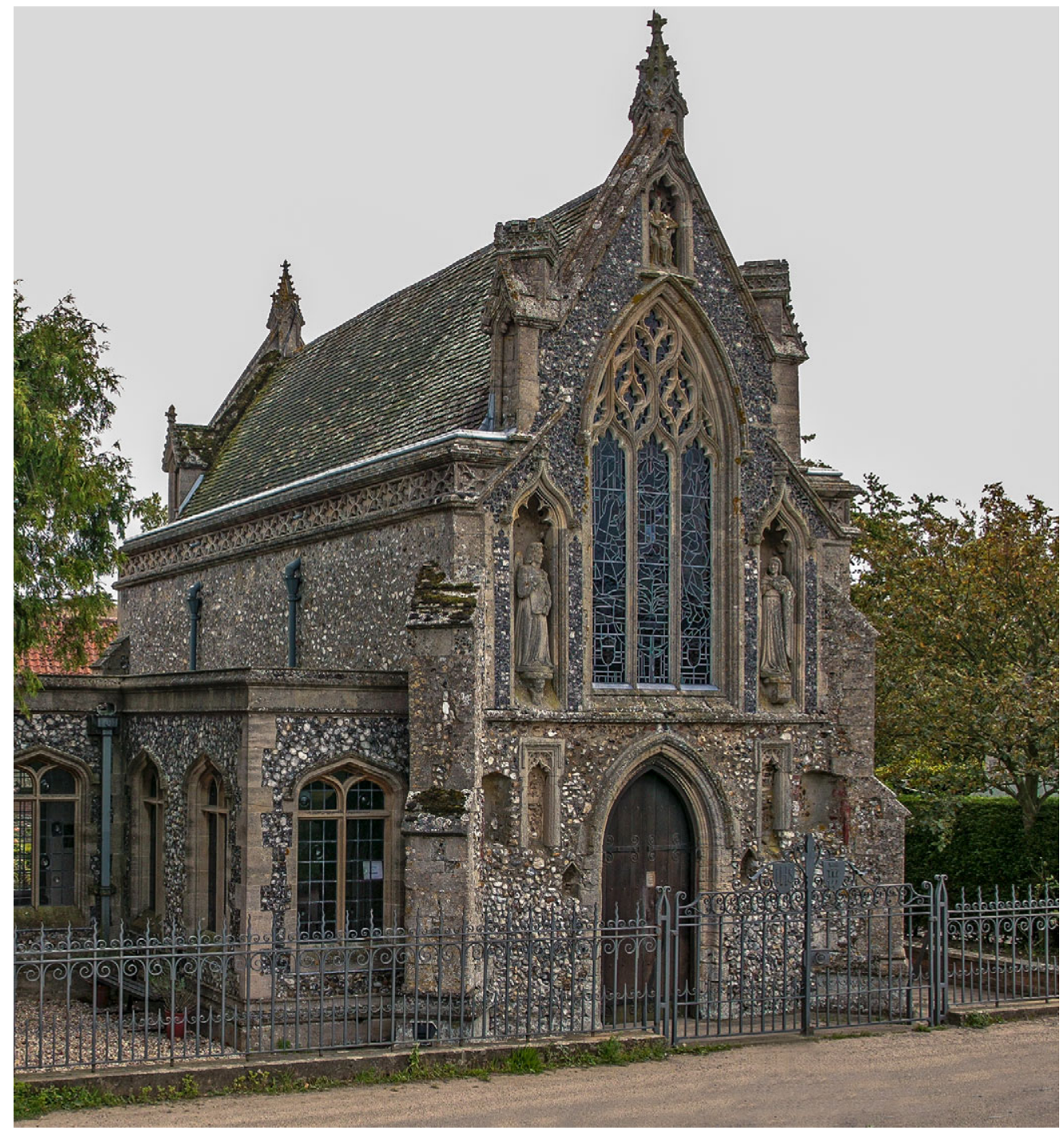

6.5 Slipper Chapel, Walsingham (Norfolk). Reproduced by kind permission of Graham Howard 
Like Glastonbury, an example was made of Walsingham at the Dissolution, with eleven monks and choristers put to death following a rebellion in I537. The priory and shrine were destroyed in the following year. In contrast with Glastonbury, however, the site and its legends lay dormant until the late nineteenth century, when interest was revived by the combined forces of Catholic emancipation, the Oxford Movement and the rise of antiquarianism. The Slipper Chapel was the first site in Walsingham to be restored as a focus for Catholic pilgrimage. It was purchased in I896 by a wealthy local heiress, Charlotte Boyd (I837-I906), after she had visited Glastonbury Abbey and identified her life's work in the restoration of medieval monastic buildings (Coleman 2004: 55). She restored the chapel, and following her conversion to Catholicism, she placed it in the care of Downside Abbey (Somerset), the senior Benedictine monastery in England. Attempts were also made to purchase the site of the Augustinian priory at Walsingham but these were unsuccessful. The Slipper Chapel emerged as a major site of pilgrimage in I934, when it was declared the Catholic National Shrine of Our Lady, in a national pilgrimage event attended by at least Io,ooo people.

A rival Anglican shrine was established in I93 I by Walsingham's high Anglican priest, Alfred Hope Patten (I885-I958) (Yelton 2006). He secured land in the village and built his own replica of the Holy House, incorporating a statue of Our Lady of Walsingham (Figure 6.6). Patten's writings acknowledge the fierce competition between the Anglican and Catholic shrines throughout these years (Coleman 2004: 58). The Catholic shrine was located at the original Slipper Chapel, an authentic locale associated with the medieval cult of Walsingham. Patten's shrine had no direct spatial connection to the medieval site of the Holy House. Instead, he created a sense of authenticity through replication, using architectural reconstruction and incorporating medieval spolia. He collected I70 fragments of medieval carved stones from the sites of dissolved medieval monasteries and incorporated these within the walls of the new Holy House (Coleman 2004: 59). These stones were not from Walsingham but they were medieval and monastic, their materiality lending a borrowed sense

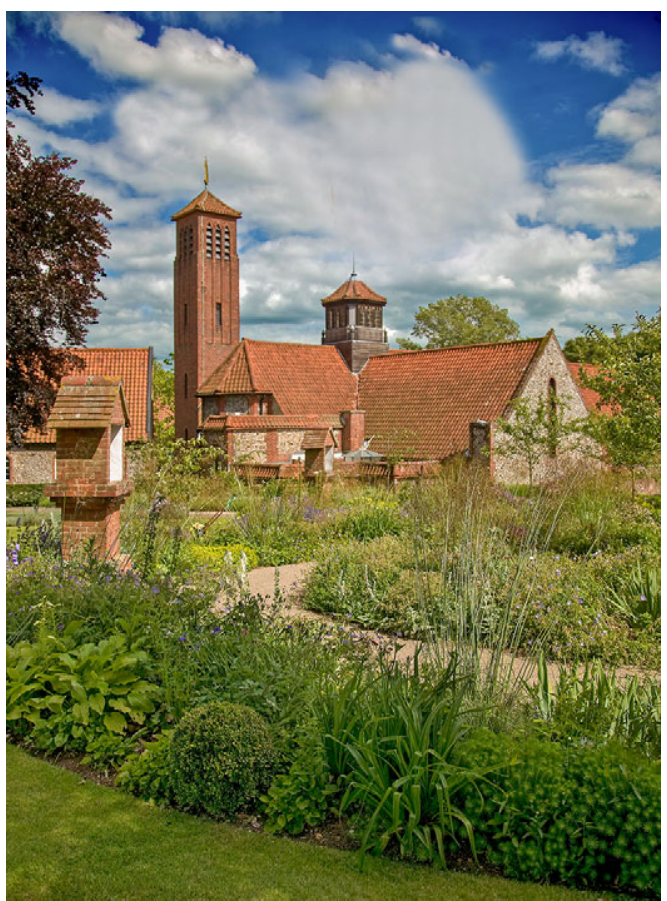

6.6 Anglican Shrine of Our Lady of Walsingham (Norfolk). Reproduced by kind permission of Graham Howard 


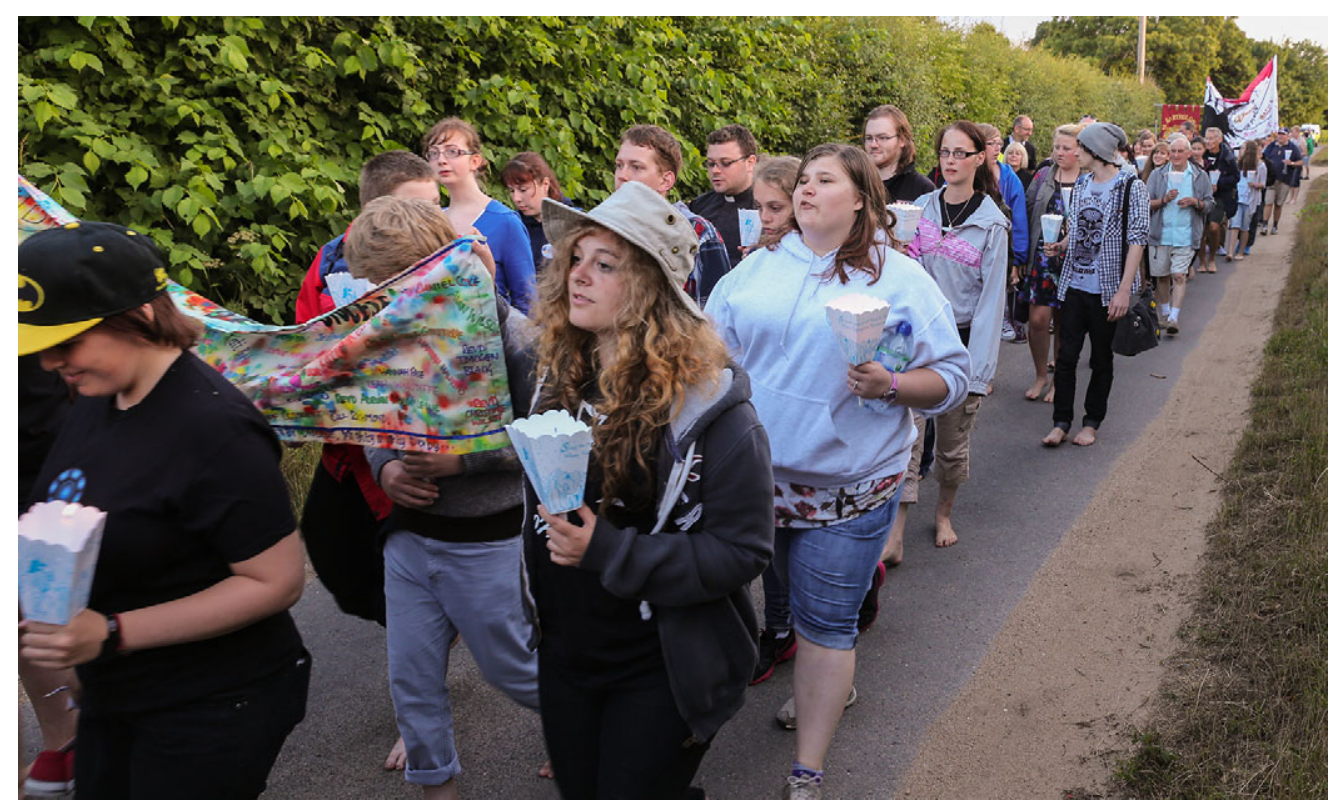

6.7 Pilgrimage at Walsingham (Norfolk). Reproduced by kind permission of Graham Howard

of 'age-value' to the new shrine (Holtorf 2013a). In digging the foundations for his replica, Patten claimed that he had found archaeological evidence for a holy well associated with the medieval Holy House. He reconstructed the well next to the replica Holy House, implying that it occupied the original space of Richeldis's building. Patten even claimed to have experienced spiritual visions of medieval Augustinian canons, who materialised to confirm the accuracy of his reconstruction (Coleman 2004: 59). Today, religious competition at Walsingham is mediated by ecumenicalism and the concern with historical authenticity is less overt. The pilgrimage experience focuses instead on processions and movement through the landscape, including a barefoot pilgrimage of the 'holy mile' from the Slipper Chapel into Walsingham village (Figure 6.7).

Similar concerns with material authenticity can be seen at the sites of medieval monasteries that were reinstated as religious houses in the twentieth century. For example, the substantial ruins of the thirteenth-century nunnery at Burnham (Buckinghamshire) were acquired by the Society of the Precious Blood in I9I6. An Anglican convent was established on the site and efforts were made to reuse the medieval spaces for their original religious purpose. The community adopted the Augustinian Rule that had been followed by the medieval nuns and they revived the most austere elements of medieval religious practice. For instance, they observe a daily watch before the Blessed Sacrament, lying prostrate before the altar, and at one time they supported an enclosed anchoress as part of the twentieth-century community (Gilchrist I989). Comparisons can be made with the abbey of Pluscarden (Moray), 
originally founded in I230 by Alexander II as a Valliscaulian priory (Fawcett 1994a: 70-2). The monastic ruins were extensive but poorly conserved when they were given in 1943 by Lord Colum Crichton-Stuart to the Catholic community of Prinknash Abbey (Gloucestershire). The site was re-established as an abbey in 1948 and continues to welcome visitors on religious retreat, many of whom engage in manual labour in keeping with the values of the medieval Valliscaulian order. At both Burnham and Pluscarden, authenticity is established through place, materiality and embodiment, nurturing a sense of continuity and personal identification with medieval religious experience. Continuity of place reinforces the sense of 'timelessness' that

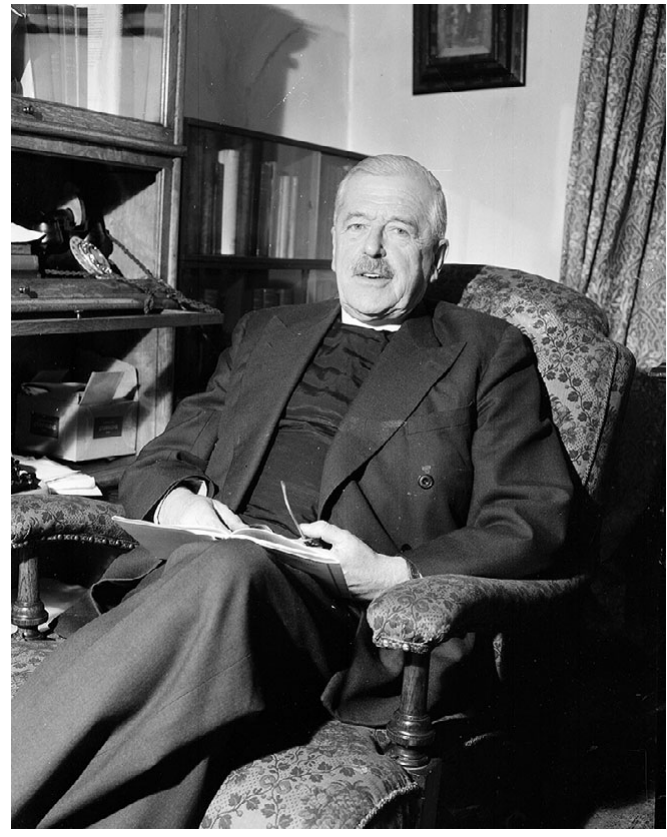

6.8 George Fielden MacLeod (I895-I99I).

(C) The Scotsman Publications Ltd is a characteristic experience of sacred heritage sites (see Chapter I), a ritual space of 'otherness' that exists outside of real time (Andriotis 20II; Shackley 2002).

Perhaps the most interesting case of medieval replication is that of Iona (Scottish Inner Hebrides), where the Iona Community was established in I938 by George Fielden MacLeod (I895-I99I) (Figure 6.8). MacLeod was Oxford educated and heir to a baronetcy, yet he was ordained as a Church of Scotland minister and developed a lifelong concern with social inequality, pacifism and ecumenicalism (Ferguson 200I). His ministry in Govan during the depression of the I930s brought him into direct contact with the most austere poverty and social deprivation. His goal was to train ministers in a different way of thinking, to bring them together with working men in a common goal. His vision focused on rebuilding the monastic quarters of the medieval abbey of Iona, with the shared labour of reconstruction shaping a new religious movement. A contemporary observer recalls:

George thought something new was needed - an experiment - and it came down to this: why not rebuild the ancient buildings on Iona where he'd often been on holiday? As Columba had experimented in Christian living and sharing, why not get a team and go there?

(Uist Macdonald, quoted in Muir 20II: I5)

Iona had attracted artists, writers and antiquaries from the late eighteenth century onwards (Christian and Stiller 2000). The abbey church had been 


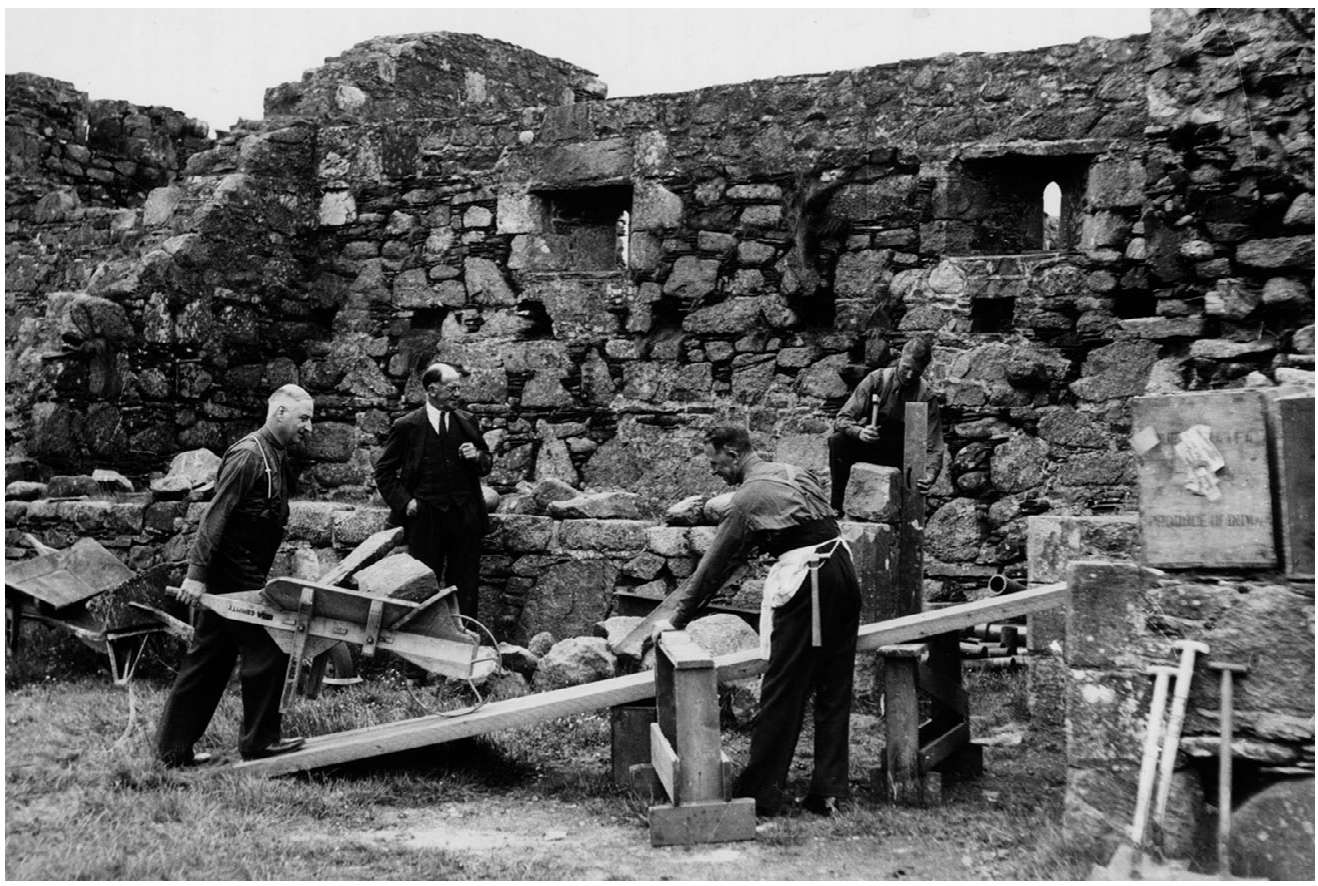

6.9 Craftsmen at Iona Abbey reconstructing the refectory in I939 (Scottish Inner Hebrides). (C) Newsquest (Herald \& Times)

restored in the late nineteenth and early twentieth centuries: the choir, transepts and crossing from $1902-5$ and the nave from I908-Io (RCAHMS I982: 55). This work pre-dated the Iona Community and was completed according to a different conservation ethic, with the work praised subsequently for its 'scholarly restraint' (RCAHMS I982: 27). The monastic ruins were given by the Duke of Argyll into the care of the Iona Cathedral Trust on the condition that they were used for worship by all denominations (Power 2006: 38).

MacLeod persuaded the trustees to permit him to reconstruct the abbey buildings and he collected the funds and personnel to enable his vision (Muir 20II: I5). He recruited young ministers, while a master mason, Bill Amos, convinced skilled craftsmen to spend their summers in Iona working alongside them (Muir 20II: I9, I52) (Figure 6.9). The restoration was carried out to the design of architect Ian G. Lindsay (I906-66), and took place over summer months from I938 to I965 (RCAHMS I982: 55). The abbey's medieval buildings were well-preserved; for example, parts of the east range and the refectory stood intact almost to the level of the wall-head (Figure 6.ro). Only the west range was a completely modern addition (dated 1965) and did not reuse medieval footings. St Michael's Chapel, the infirmary (now museum) and the lavatory block were also reconstructed from medieval remains (Muir 20II: I25-37). The rebuilding copied medieval detail where possible; for 


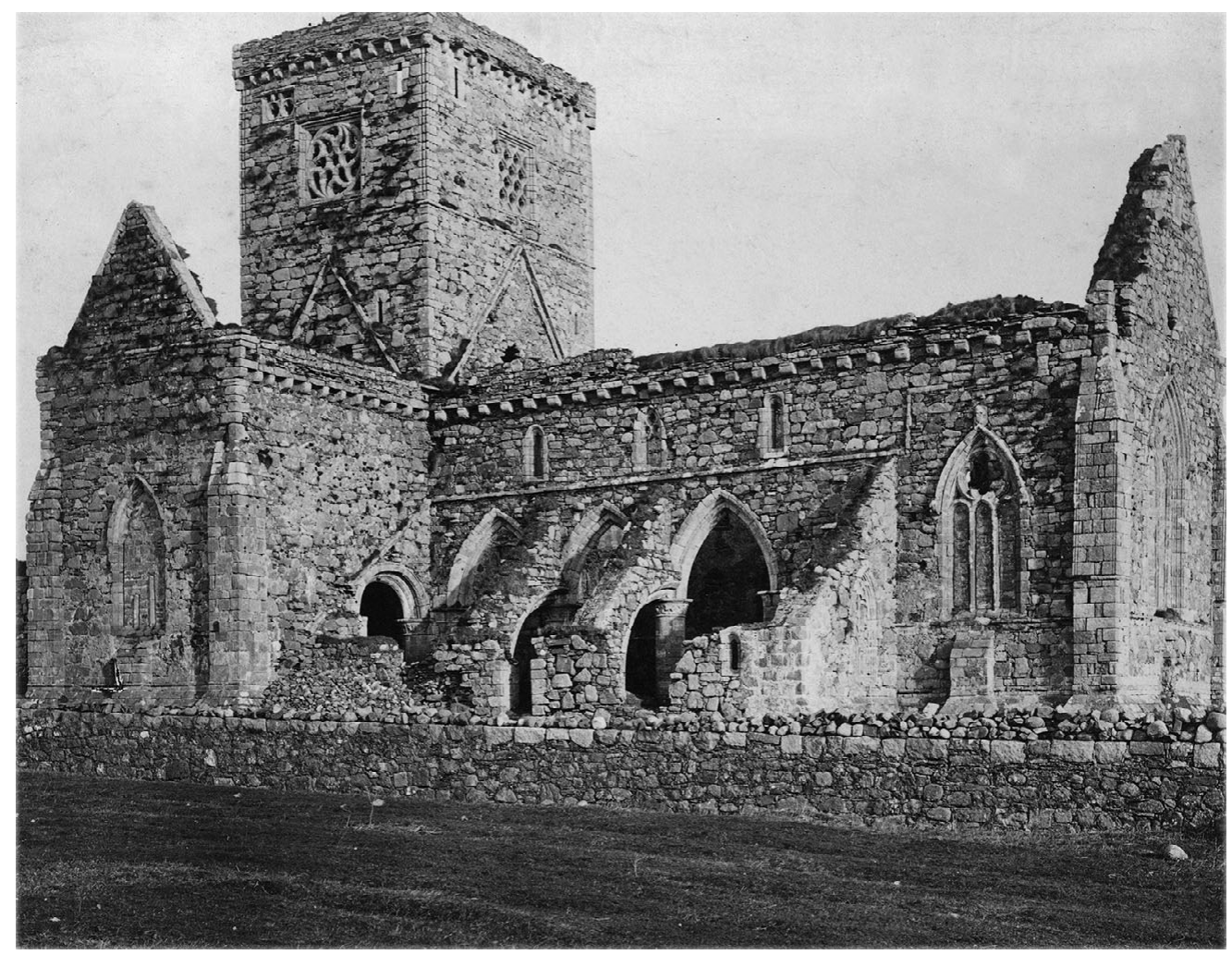

6. Io Iona Abbey (Scottish Inner Hebrides) before restoration (c.1874). C) Royal Commission on the Ancient and Historical Monuments of Scotland

example, the cloister arcades built in 1959 were modelled on the early thirteenth-century cloister (Muir 20II: I23-4). Today, the church and monastic complex appear deceptively homogeneous, due to the consistent use of the same local building materials.

MacLeod's model for the lifestyle of the Iona Community was grounded in monasticism, as well as his own military training during the First World War. He forged a masculine community based on discipline, manual labour, daily worship and the communal life, which included sharing meals, labour and leisure (Muir 20II: 28). This fellowship was entirely male - married men had to leave their wives behind in Glasgow. The first woman was admitted to the Iona Community only thirty years later, in I969, after MacLeod had stepped down (Power 2006: 39). MacLeod was influential in framing Iona as a 'thin place', a concept that has become central to the Celtic spiritual revival. This refers to the idea that in certain sacred places, the 'veil is thin' between this world and the next. He used this term repeatedly from the I930s onwards, drawing on biblical references to the veil of the Temple (Hebrews 6:19; 2 Corinthians) to emphasise the thin separation of the material world from the spiritual realm (Power 2006: 45). In Celtic spirituality, 'thin places' are believed 
to allow spiritual seekers to hear and see God more clearly. It is a central concept in the development of Protestant pilgrimage practices in modern Britain, one which does not carry the Catholic overtones of medieval pilgrimage traditions. The concept of 'thin places' also resonates with the eremitic tradition of Celtic monasticism, with its close connection to nature and a sense of living on the edge of the world (Walton 20I5: 34-5) (Figure 6.II).

MacLeod was interested in the spiritual authenticity of place and the physical act of reconstruction - but he was not troubled by specific details of archaeology. He manipulated historical and archaeological evidence to support his version of Iona's past, with apparently little challenge from the academic community (Power 2006: 48). A telling example is the reconstruction of St Columba's Shrine, completed in 1962 to the architectural design of Ian Lindsay. Archaeological evidence for a critical feature was omitted: the side walls originally extended to the west to form antae, or buttresses in the Irish tradition, that indicate a date of the ninth to tenth century (RCAHMS I982: 42). This lack of attention to archaeological evidence is significant, given that the architect, Lindsay, was a close personal friend of J. S. Richardson, principal inspector of Ancient Monuments for Scotland. Richardson had intervened personally to ensure that Lindsay received the commission for the work at Iona (Dictionary of Scottish Architects).

Archaeological input came surprisingly late to Iona: limited recording took place in relation to clearance operations in the I870s and architectural conservation in the I940s (O’Sullivan I999: 223; RCAHMS I982: I37). Lindsay made some attempt to involve the architect and archaeologist Edwin William Lovegrove (I868-I956) in the work at Iona. However, this proposal was rejected by both the Iona Community and the Ancient Monuments inspectorate (Ian Fisher, pers. comm.). The first serious excavations did not take place until work for the Russell Trust, led by Charles Thomas from I956-63 (RCAHMS I982: 224; Campbell and Maldonado 20I6). Rescue excavations in the I960s responded to proposals for new buildings put forward by the Iona Community, with small-scale research excavations targeted on the claustral complex in the I970s, after the architectural reconstruction was completed (Reece I98I).

The reinstatement of Glastonbury Abbey as a sacred site could not have been more different. Archaeology and preservation of fabric were central to the endeavour and efforts to reconstruct or replicate medieval fabric were limited. The site of Glastonbury Abbey was offered for sale in 1906, featuring the monastic ruins in the landscaped park of Abbey House, a gentleman's residence built in I830. There was national interest and speculation that the ruins would be purchased either by the government for the nation or by the Catholic Church. The site was eventually purchased for the Church of England by the Diocese of Bath and Wells, for the sum of $£ 30,000$ (Gilchrist 


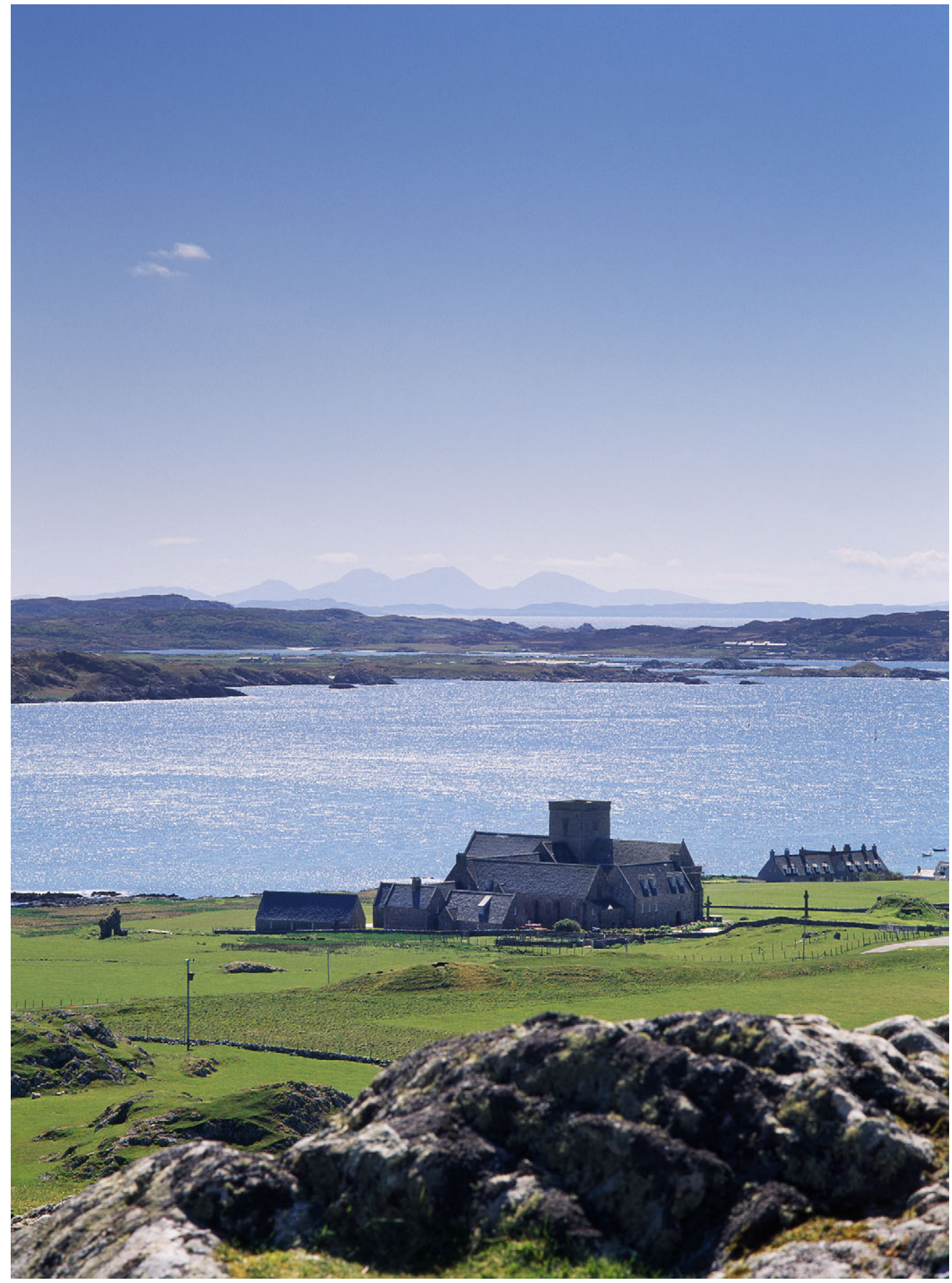

6. I I Iona Abbey (Scottish Inner Hebrides). (C) Mick Sharp 
and Green 2015:9). This is a unique case of the Anglican Church actively acquiring a medieval monastic ruin, one perceived as a national shrine that they wished kept in Anglican control. A leading conservation architect, W. D. Caroe (1857-I938), was appointed by the abbey trustees and archaeological excavations were commissioned immediately to inform the site's conservation and interpretation. Frederick Bligh Bond (I864-I945), architect to the Diocese of Bath and Wells, was appointed as the first director of the archaeological programme, conducting excavations from I908-2I. The trustees intended the excavations to clear and consolidate the ruins and to trace the earliest Saxon and Norman churches (Gilchrist and Green 2015: 9-I7).

However, the abbey's first archaeologist was driven by a personal research agenda linked to his own spiritual motives. Frederick Bligh Bond was intensely interested in the legendary history of Glastonbury and he is regarded as a pioneering figure of the New Age movement. His investigations integrated psychic experiments, dowsing and spiritualism, the belief that the spirits of the dead can communicate with the living. He developed his own interpretation of spiritualism, proposing that ancient memories from the unconscious could be channelled through the medium of automatic writing (Hopkinson-Ball 2007: II3). Automatic writing is an alleged ability to produce written words from a subconscious, spiritual or supernatural source. This psychic method gained currency in the late nineteenth and early twentieth centuries, with celebrated proponents including Sir Arthur Conan Doyle. Psychic methods also guided archaeological investigations at the Cistercian abbey of Villers (Belgium) in 1938, where the Jesuit Father Lepers used divination based on the alleged detection of emitted radiation (Coomans 2005: 54). At Glastonbury, Bond attempted to use archaeology both to verify Glastonbury's legendary history and to validate his methods of psychic research. He sought archaeological proof of the connection with Joseph of Arimathea and his foundation of a church at Glastonbury in $63 \mathrm{CE}$, after historians had begun to question the veracity of the documentary sources (Hopkinson-Ball 2007: I83). This approach can be compared with early biblical archaeology, and indeed one of Bond's patrons in this work was Sir Charles Marston, the wealthy chairman of Villiers Engineering, who was a great exponent of biblical archaeology.

Bond's second proof was more unorthodox: he used archaeological excavation as a method to prove the scientific value of automatic writing. This is best illustrated by the celebrated case of the Edgar Chapel, located at the eastern termination of the abbey church. Automatic writing suggested to Bond that the Edgar Chapel had an apsed termination, but this feature was not confirmed by his excavations. Despite the absence of archaeological evidence, Bond showed an apsed chapel on his published plans of the Edgar Chapel and reconstructed the apse on site in I909, using large concrete blocks. In a book 
published in I9I8, he revealed that his excavations at the abbey had been an extended experiment in psychical research: The Gates of Remembrance: The Story of the Psychological Experiment which resulted in the Discovery of the Edgar Chapel at Glastonbury (Bond I9I8). Bond considered his psychical research to be entirely consistent with his commitment to Christianity; indeed, he argued that he was conducting 'sacred archaeology' at Glastonbury (Hopkinson-Ball 2008).

The Anglican trustees were surprisingly tolerant of these approaches. However, Bond was eventually dismissed in 1922, owing as much to controversy in his personal life and finances, as to irregularities in his archaeological field practice. Bond's reconstructed layout of the Edgar Chapel was quietly removed and the trustees appointed more traditional ecclesiologists to conduct excavations up to the outbreak of war in I939, resuming in the I950s and I960s with the excavations led by Ralegh Radford (Gilchrist and Green 2015: I5). To the present day, Glastonbury Abbey has remained highly conservative in its site signage and presentation of the ruins to the public. There is no reconstruction of fabric and only minimal efforts have been made to show the layout of the church and cloister. The ruins are dominated by the Lady Chapel, also known as St Joseph's Chapel, which remains largely intact (see Figure 5.5). The chapel was built soon after the fire of II 84 destroyed the early church associated with the Arimathea legend (see Chapter 5). This hallowed structure represents the sacred heritage of Glastonbury Abbey and its claim to authenticity as the cradle of English Christianity. However, only those closely familiar with the Glastonbury legends would automatically connect the chapel with the Arimathea story. In their approaches to site presentation and conservation, the Glastonbury trustees have been starkly minimalist. The obvious question is this: why were the approaches of replication and reconstruction rejected at Glastonbury, when they were applied at Walsingham and Iona?

The answer lies in Glastonbury's engagement with emerging national policy on monument conservation and the impact of the Ancient Monuments Act I9I3. The development of Glastonbury Abbey as a public monument took place at precisely the time when the English 'preservation ethic' was being established and when prominent medieval abbeys such as Rievaulx, Whitby and Fountains (North Yorkshire) were taken into 'guardianship' to preserve them for the nation (Emerick 20I4). The key architect of this national plan was Sir Charles Peers (I868-I952), Chief Inspector of Ancient Monuments for the Ministry of Works. Peers promoted a distinctive approach to the preservation and display of ruins which aimed to preserve medieval authenticity - later fabric was stripped away to reveal the principal period of construction. Monuments were repaired or preserved 'as found', and set within simple, grassed lawns with minimal interpretation, projected as 'dead' monuments 'frozen' in time. Reconstruction was abhorrent to Peers and the emerging field of heritage professionals; replication was considered a threat to the integrity of medieval fabric (Emerick 20I4: 83-98). 


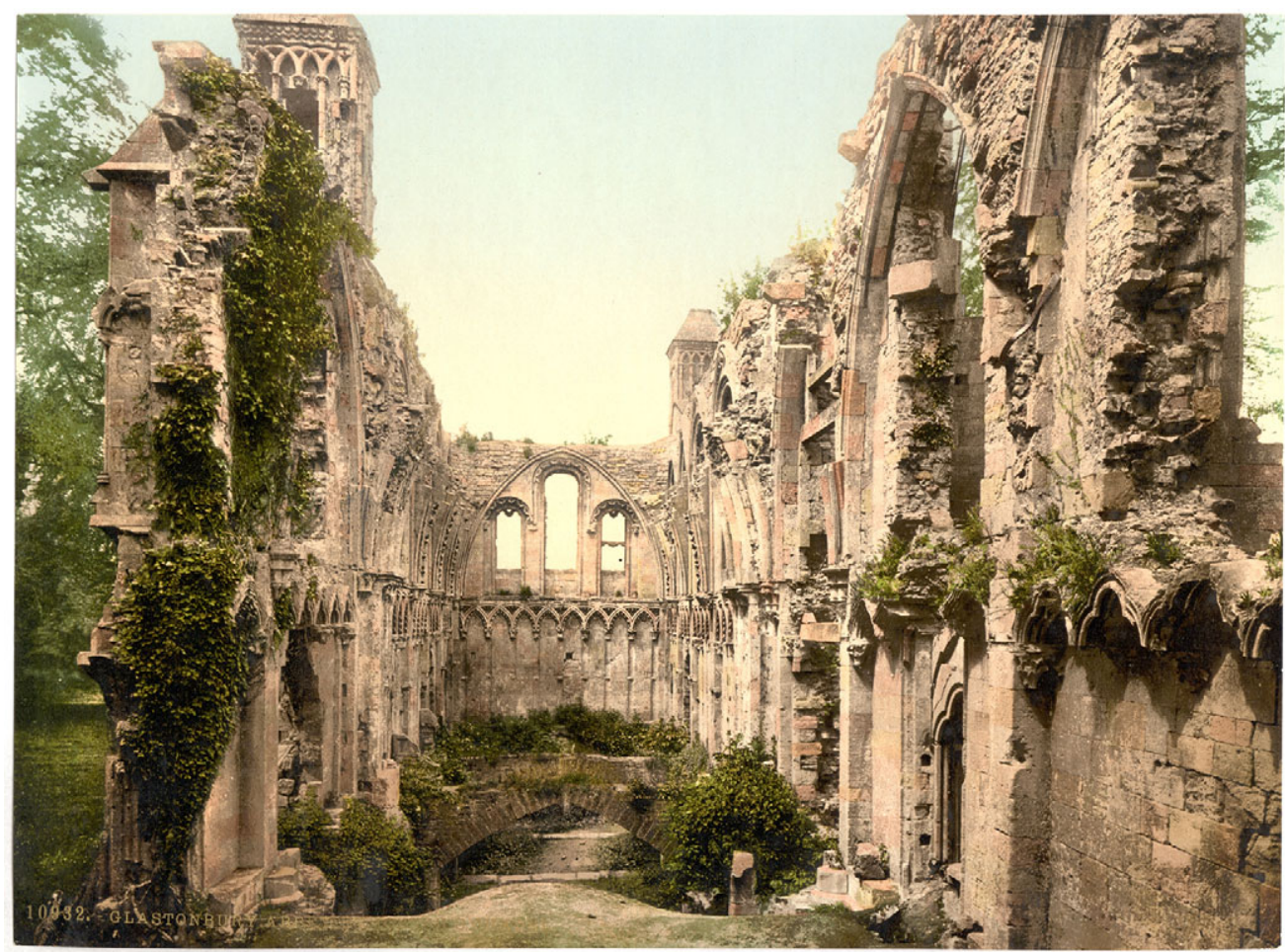

6. I 2 Glastonbury Abbey's Lady Chapel (Somerset) c.1900, before restoration. United States Library of Congress, Public Domain

The first phase of conservation work at Glastonbury disregarded the emerging philosophy on preservation. The conservation architect, Caroe, initiated major interventions to the Lady Chapel and the Galilee, reinstating a lost bay in the north wall, reconstructing the southwest corner turret and building a prominent new strainer arch to the east. Missing sections of wall-top were reinstated to their original height, possibly with the intention of reroofing the Lady Chapel, a contentious proposal that was debated periodically by the trustees up to 1939. Caroe also undertook controversial works in the church which altered the profile of the ruin, rather than conserving it as found' (Figure 6.12). For example, he transformed the east wall of the crossing tower by facing the exposed core with ashlar in a series of curved corbels. The trustees' minutes indicate that they were not happy with the work and would have replaced it, had funds been available (Glastonbury Abbey Conservation Plan 20I8).

Caroe's early work at Glastonbury (1908-I3) was criticised locally and nationally. The Ancient Monuments Act I9I3 provided the instrument for the state to intervene and Glastonbury Abbey was scheduled as a protected monument in I9I5. Charles Peers reported his concerns about Glastonbury to the Ancient Monuments Board, describing Caroe's work as 'greatly in excess 
of anything needed for the preservation of ruins', and lamenting in private correspondence that Caroe's work to the Galilee was a 'beastly botch' (Glastonbury Abbey Conservation Plan 20I8, citing PRO WORKS I4/69I 07II80/2 pt I). Peers influenced work at Glastonbury from I9I5 onwards, in his capacity as Chief Inspector of Ancient Monuments; he became more deeply involved as joint director of excavations at Glastonbury Abbey I928-39, and subsequently as the abbey's conservation architect, following the death of Caroe in 1939. Under Peers's direction, the excavations at Glastonbury focused on the removal of building debris in order to consolidate the fabric, with very little disturbance to underlying deposits (Gilchrist and Green 2015: I2-I5). Although Glastonbury Abbey is owned and managed by a private trust, it resembles an English Heritage guardianship site for all intents and purposes, even down to the Ministry of Works style signage that survives to the time of writing (20I8). This reflects the personal involvement of Charles Peers and Glastonbury Abbey's close engagement with the national preservation ethic. The public presentation of Glastonbury Abbey projects a particular style of authenticity that emerged in the inter-war years, staging medieval monasteries as frozen in time and masking the substantial clearance and conservation works that were undertaken in the early twentieth century.

\section{SPIRITUAL IDENTITIES: CONTESTED HERITAGE}

\section{AND SACRED SITES}

Multiple and competing religious narratives are frequently attached to sacred heritage sites: spiritual authority is contested and tensions emerge over access for the performance of religious rituals (see Chapter I). These themes have been explored by archaeologists at World Heritage sites ranging from Stonehenge to Great Zimbabwe (Hodder 2008). At Stonehenge, pagan ritual engagement with the monument has come into conflict with the preservation ethic of heritage management. Votive offerings of candles and chalked symbols are regarded as a conservation threat to the stones and raucous celebrations are considered to compromise the quiet reverence deemed appropriate to a sacred site (Wallis and Blain 2003: 3I6). At Great Zimbabwe, interpretation and access are framed by the site's 'Authorized Heritage Discourse' (Smith 2006) as an early international trading site. There are also local understandings of the site among the Shona-speaking communities, including religious specialists (masvikiro) who claim to communicate with spirits who provide connections to ancestors (Fontein 2006). Joost Fontein's ethnographic study of Great Zimbabwe reveals that local religious understandings and sense of place have been silenced by dominant archaeological narratives. The local religious specialists believe that the ancestors have turned their backs on Zimbabwe due to desecration by archaeologists, including programmes of excavation, 
reconstruction and replication, and because traditional rituals are no longer permitted at the site. The ancestors used to whisper from the walls of Great Zimbabwe, but now they are silent.

Archaeologists have been alert to contemporary spiritual conflicts focusing on prehistoric sites, but they have not considered how these questions relate to sites of medieval Christianity. Medieval sacred sites in Britain are also subject to ongoing tensions over spiritual authority, ritual access and competing religious narratives. Early Christian sites such as Iona, Glastonbury and Lindisfarne remain highly significant to the Anglican and Catholic Churches, and they are also beacons for Celtic spirituality and neo-pagan beliefs. The 'new Celtic Twilight' movement emerged in the late twentieth century and in common with paganism, emphasises personal development and individual spiritual capabilities (Power 2006; Rountree 2006). Rosemary Power has set out the defining characteristics of Celtic Christianity. The movement emphasises: a focus on sense of place and interest in nature/environment; a connection with folk practices and the lives of early saints; belief that Celtic worship was spontaneous, incorporating dance, music and self-expression; belief in the equality of women in both the early Celtic church and today; a sense of liminality, being on the edge spiritually and organisationally; and distrust of ecclesiastical structures and rigid liturgy (Power 2006: 34). The Iona Community has found itself at the heart of this movement, although many of the values are completely opposed to George MacLeod's original vision, which was highly structured, institutional and male. The Community's commitment to ecumenicalism has enabled it to thrive and interact with late twentieth-century models of Celtic spirituality.

Glastonbury has attracted a diverse range of spiritual seekers for over a century. The abbey itself draws nearly I00,000 visitors each year, while the wider sacred landscape of Glastonbury entices many thousands more, followers of Christianity, Wicca and Druidry. The natural landscape is an important factor in Glastonbury's allure, combining with its religious ancestry to create a palpable sense of place. The abbey sits on a promontory above the surrounding marshlands; in the early Middle Ages, Glastonbury would have been a monastic island surrounded by water. A natural sandstone pinnacle towers over the abbey and town: Glastonbury Tor is visible for up to 25 miles $(40 \mathrm{~km})$ in all directions, crowned by the tower of the ruined medieval chapel of St Michael (Figure 6.I3). In the early twentieth century, Glastonbury became the focal point for spiritual, creative and esoteric movements. A holy well located at the base of the Tor attracted a group of artists and spiritualists known as the Avalonians. The waters of Chalice Well contain iron oxides which leave a red deposit when dry - the red staining was explained through reference to the myth of Joseph of Arimathea (Mather 2009). It was claimed that when he arrived in Glastonbury, Joseph washed the Holy Grail in the spring, and 


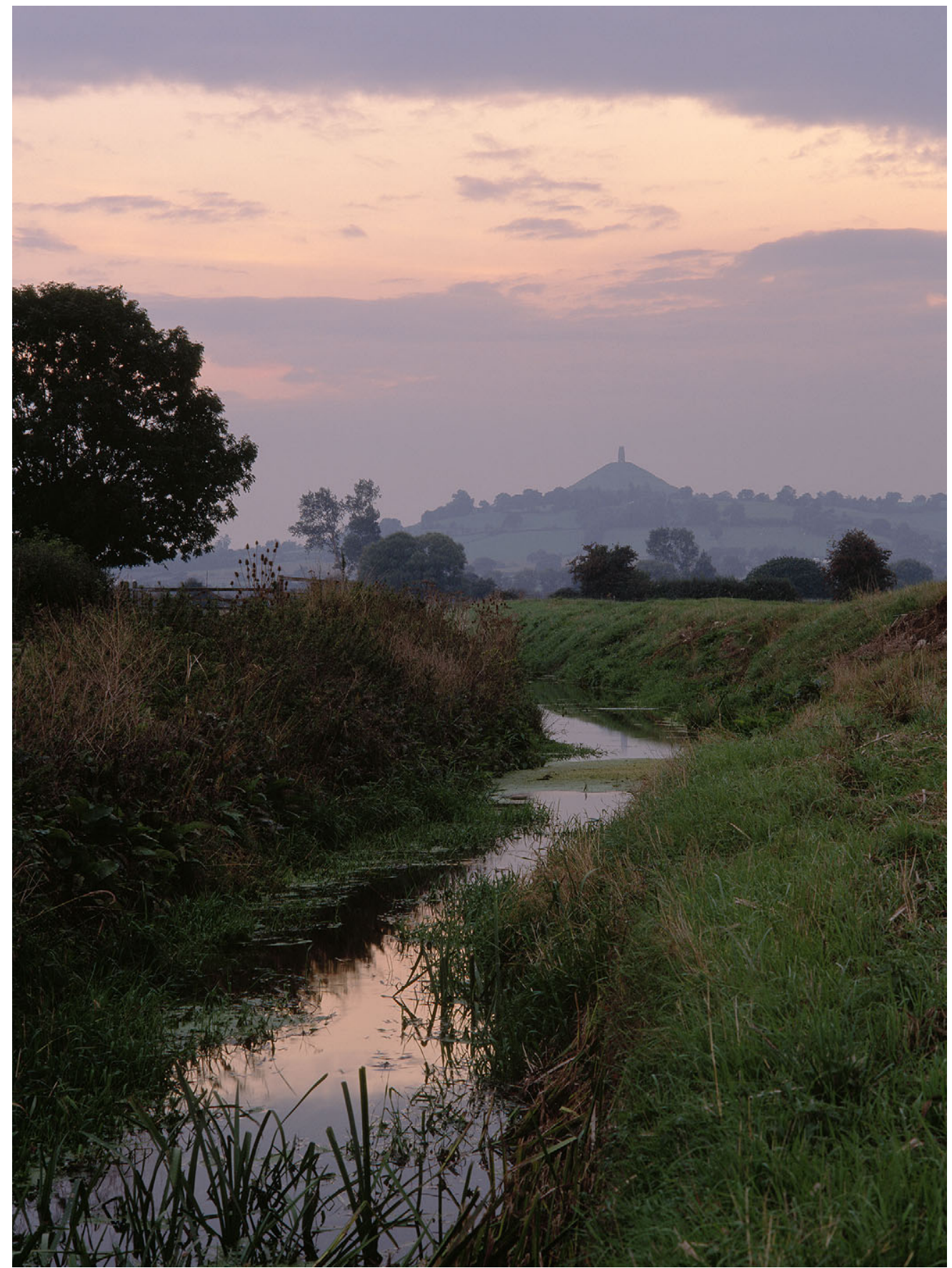

6. I 3 Glastonbury Tor (Somerset). C Mick Sharp 


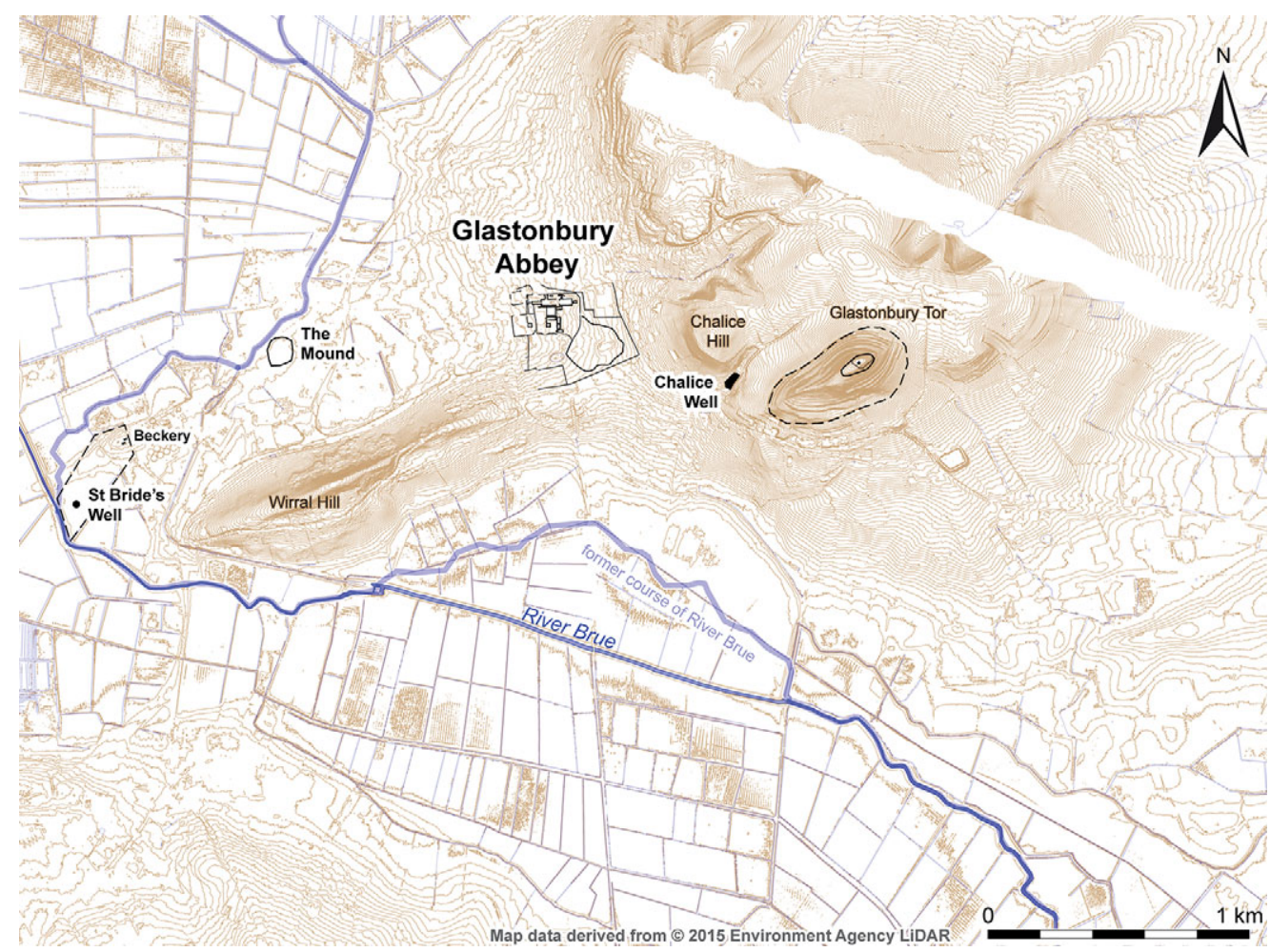

6. I 4 Sacred sites in Glastonbury (Somerset). (C) Liz Gardner

Christ's blood blessed the healing waters. The site was purchased by Alice Buckton in I9I2, a Christian socialist, and she established a centre of traditional crafts at Chalice Well. Glastonbury became a place of pilgrimage for Christian mystics as well as a beacon for music and the performing arts (Hutton 2003: 63-4). Miss Buckton's Chalice Well School of Pageantry became the headquarters of the Glastonbury Crafts Guild and the Folk-Play and Festival Association. In I9I4, the musical composer Rutland Boughton founded a community of musicians and artists at Glastonbury intended to rival London's musical establishment, and modelled on Wagner's Bayreuth. He established the first Glastonbury Festival, which survived until I926, performing musical dramas based on Arthurian legends and taking inspiration from the abbey (Glastonbury Abbey Conservation Plan 2018). Glastonbury emerged as a magnet for the New Age from the I970s, attracted by the modern Glastonbury Festival, which was established by Michael Eavis at nearby Pilton and has grown to be a leading international festival of performing arts.

Glastonbury is rare in the English religious tradition in representing a sacred landscape of multiple components, principally the abbey, the Tor and Chalice Well (Figure 6.I4). It embodies the cult of 'topophilia', a term coined by W. H. Auden (I947) to describe how people experience a strong 
sense of place and how locations become integral to identity and belonging (Tuan 1990). Certain locations are believed to be inherently powerful and to have special qualities: the light, air, water and landscape of Glastonbury are believed to promote healing and creativity (Bowman 2000). Like Iona, Glastonbury is a 'thin place', where the boundary between the material and the spiritual is permeable. Many elements in the Glastonbury story appeal to currents in Celtic spirituality, such as identification with the landscape and a personal quest for enlightenment, embodied by the Grail legend. Alternative beliefs have developed surrounding the history of the landscape and they are stubbornly resistant to contradictory evidence from archaeologists. For example, it is widely accepted that ley lines were important in the laying out of the town, believed by some to be ancient or mystical alignments. The physical terrain itself is regarded as having been deliberately created for symbolic reasons: many believe that the landscape of Glastonbury Tor is shaped as a maze, zodiac or reclining goddess (Ashe I979; Maltwood 1964). Since the 1960s, the terraces on the Tor have been popularly regarded as the remains of an ancient labyrinth, although archaeological survey has confirmed that the earthworks are medieval field systems likely dating to the thirteenth century (Hollinrake and Hollinrake 2003; Hutton 20I4: 353-4). Glastonbury is heralded as both the site of an early Druidic university and a prehistoric centre of the goddess cult - these claims are promoted through web platforms and social media, without the need for supporting empirical evidence (Bowman 2009).

Glastonbury also appeals to the tendency in Celtic spirituality to celebrate a past 'Golden Age'. This manifests as a focus on the site's Celtic origins and the belief that Joseph of Arimathea founded a church of British Christianity, a purer form of native Christianity that pre-dated the Roman mission to England. Glastonbury's Arthur story also feeds the Celtic 'Golden Age' narrative: Arthur was a Celtic king who fought off Saxon invaders. Some still regard King Arthur as a messiah figure, who will rise again at Glastonbury to lead the New Age. Both Joseph and Arthur connect Glastonbury to an ancient, indigenous form of British religion, appealing to alternative spiritualities such as Druidry and Wicca, while alternative interpretations of the landscape have attracted feminist exponents of the goddess cult (Rountree 2006). There is also interest in the Celtic connections claimed by the medieval monks, in particular stories recorded by the abbey chroniclers that St Patrick and St Bridget visited the monastery in the fifth century. The medieval abbey claimed to have relics of St Bridget including a bag or wallet, a necklace, a small bell and some weaving implements (Carley I996: I09). The legend of St Bridget is also associated with Bride's Mound, a small hill to the west of Wearyall Hill, in an area known as Beckery Island. Excavations at Beckery in the I96os uncovered evidence for an early monastic site and cemetery of predominantly 
male burials, while the chronicle of Glastonbury Abbey records that an early nunnery had been located near Wearyall Hill (Rahtz and Watts 2003). Reexcavation of the site in 2016 was undertaken to obtain skeletons for scientific dating. Radiocarbon dates on seven skeletons revealed dates as early as the late fifth or early sixth century, continuing into the seventh to ninth centuries (Southwest Heritage Trust 2017).

The town of Glastonbury is a multivalent pilgrimage site that has generated a unique 'spiritual services industry', based on shops, galleries, spiritual therapies and psychic services (Bowman 2009). The religious scholar Marion Bowman describes it thus:

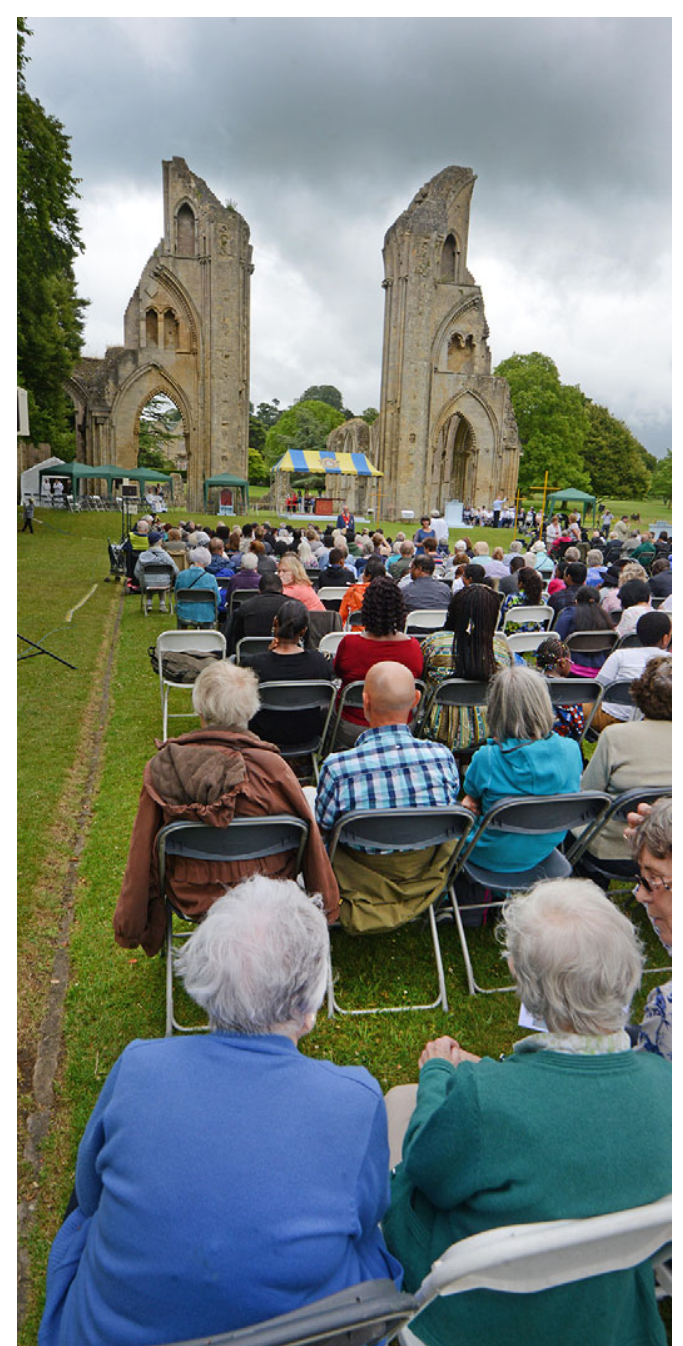

6. Is Pilgrimage at Glastonbury Abbey (Somerset) in 20I5. Reproduced by kind permission of Glastonbury Abbey
Depending on whom you talk to, or what you read, Glastonbury is considered to be: the Isle of Avalon; the site of a great Druidic centre of learning; a significant prehistoric centre of Goddess worship; the 'cradle of English Christianity' visited by Joseph of Arimathea, and perhaps even Christ himself; the 'New Jerusalem'; a communication point for alien contact; the epicentre of the New Age in England; and the 'heart chakra' of planet earth.

(Bowman 2000: 83)

The historian Ronald Hutton sums up Glastonbury succinctly as 'the British capital of dreams'. Its two main streets are lined with shops purveying crystals, incense and New Age souvenirs, where 'characters from early Celtic literature rub shoulders with shamans, dowsers and The Goddess' (Hutton 2003: 59). Bowman argues that an 'alternative Christianity' has emerged at Glastonbury, with Anglican and Catholic practices influenced by 'vernacular' and 'integrative' (New Age) religions. The spirit of place is reflected in its continuing appeal to pilgrims of numerous faiths: the abbey attracts annual Anglican and Catholic pilgrimage processions (Figure 6.15); the 


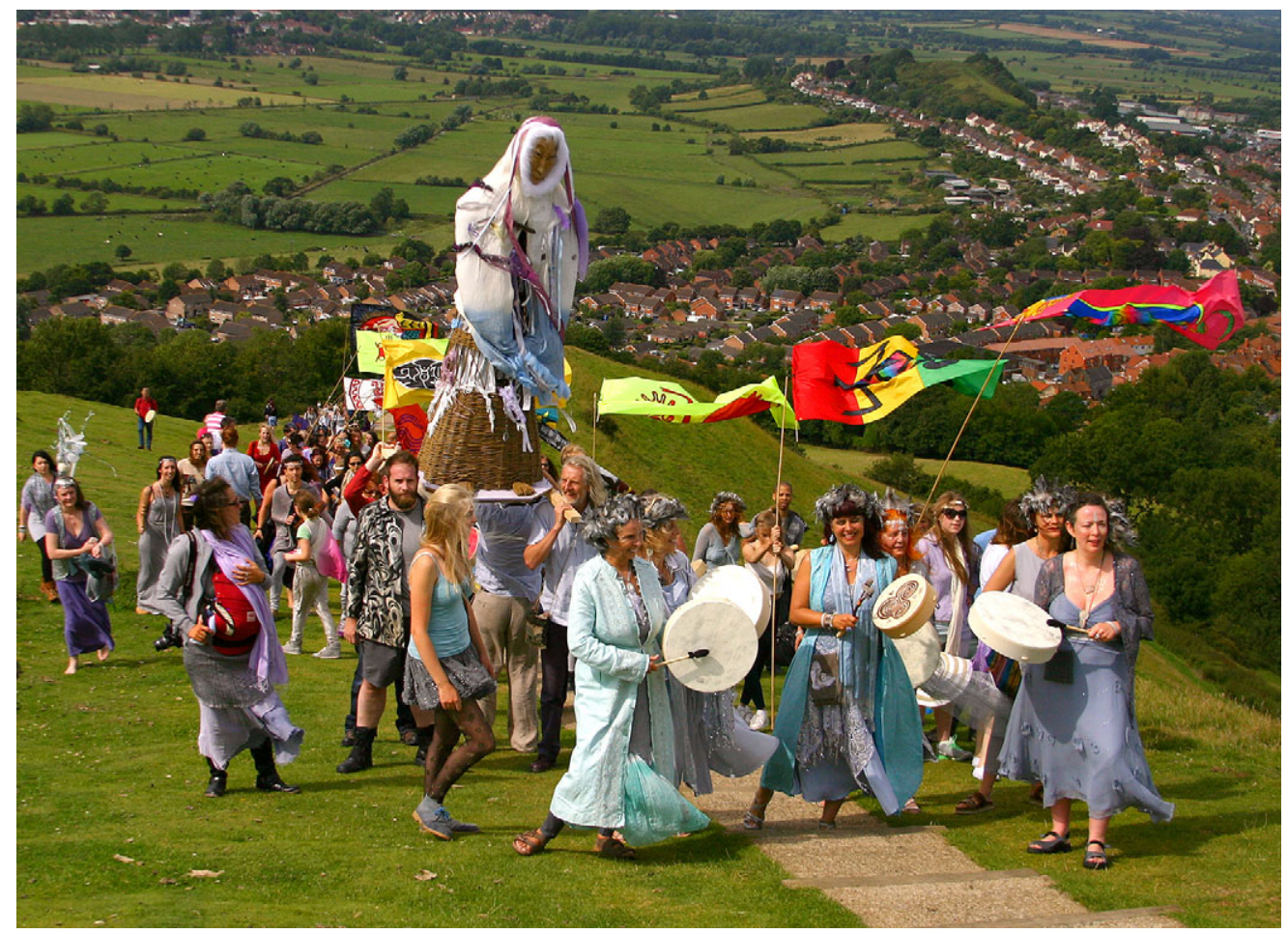

6. I6 Goddess Festival at Glastonbury (Somerset) in 2015. Reproduced by kind permission of Geoff Corris

Tor is the focus of Beltane (May Day) celebrations; and the town hosts an annual, international Goddess Festival (founded I996), in which goddesses process through the streets (Figure 6.I6).

This magnet for spiritual energy has also attracted tensions between religious groups. A poignant example is the vandalism of the Holy Thorn on Wearyall Hill - the tree which is believed to have grown from the staff of Joseph of Arimathea. The legend of the Holy Thorn emerged in the seventeenth century and the tree was a symbol of conflict during the Civil War (Walsham 2004; see Chapter 5). An annual ceremony takes place in December each year, when sprigs are cut from the Holy Thorn at St John's parish church and are sent to the Queen (Bowman 2006). Bowman identifies the Holy Thorn as an essential element of Glastonbury's vernacular religion, which brings together diverse spiritual groups in the annual ceremony. The Holy Thorn on Wearyall Hill was vandalised in 2010 and attacked on numerous occasions until it was replaced with a grafted sapling in 20I2, which was immediately snapped in half. The identities and motivations of the vandals have not been determined but both militant Christians and militant pagans have been blamed (BBC News, 4 April 20I2). The attack on the symbol of Joseph of Arimathea brought the community together in shared grief and disbelief. However, it is important 


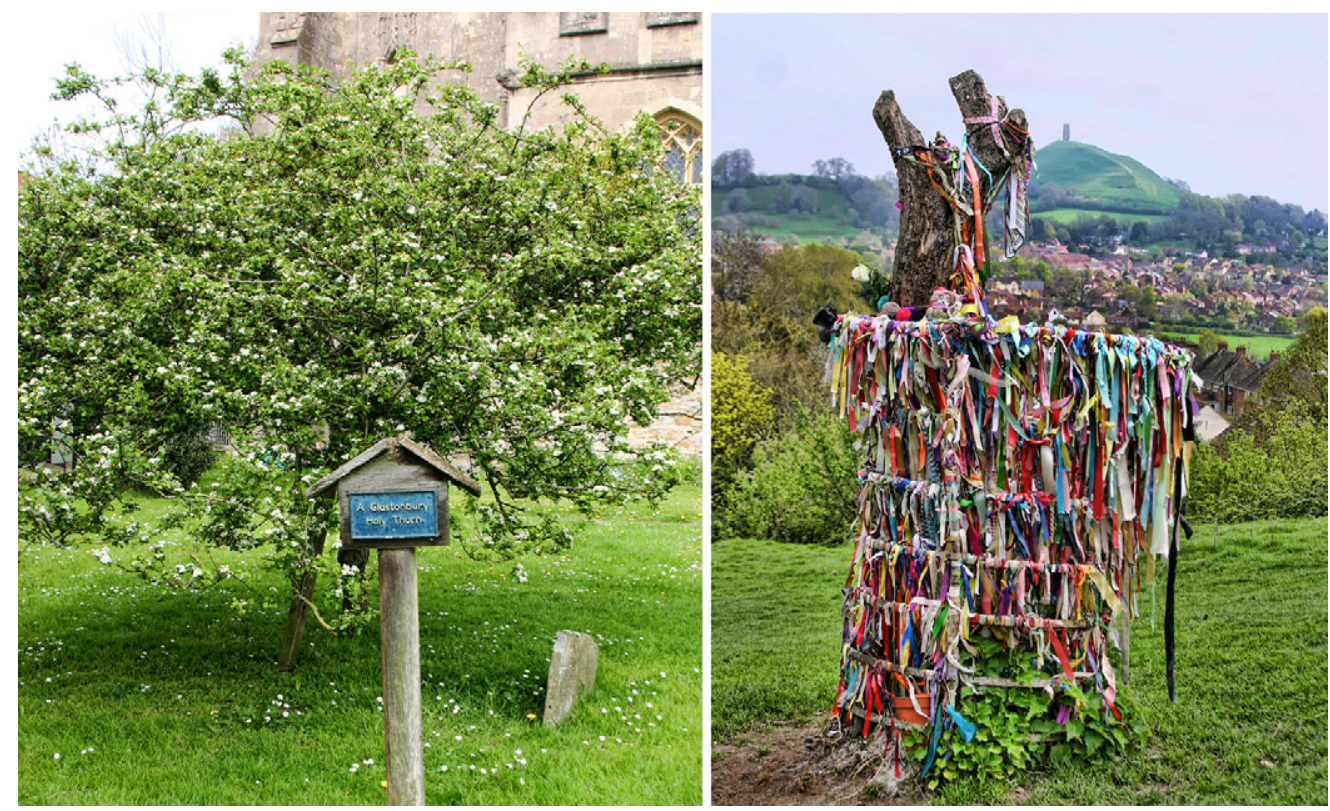

6. I 7 Holy Thorns at Glastonbury (Somerset): Wearyall Hill and St John's Church (left). Reproduced by kind permission of Geoff Corris

to understand that there are five Holy Thorns in Glastonbury, all believed to be descendants from the original thorn, and periodically replaced with new grafted trees (Figure 6.I7). For many in Glastonbury, authenticity is a relative concept; ancient symbols are valued but their historicity is not questioned too closely.

Bowman comments on how Glastonbury has become more ecumenical over the past twenty years. For example, she observes how the parish church of St John's previously put up railings to keep out the hippies - because it was believed that they posed a threat to the Holy Thorn located in St John's churchyard (Bowman 2006: I34). These barriers have now come down but access to sacred space in Glastonbury remains highly contested, particularly Chalice Well, the Tor and the abbey, with the abbey exerting strong control over what is permissible within its bounds (Bowman 2009: I67). In particular, non-Christian rituals are prohibited on abbey grounds, although illicit pagan offerings such as flowers and candles are frequently discovered, and abbey staff regularly intervene to stop pagan rituals from taking place in the grounds. Some local people complain that the abbey hides behind its medieval walls and that these should come down, to allow open ritual access and free entry to the sacred site of the abbey (Glastonbury Abbey Conservation Plan 20I8).

The abbey trustees are also committed to increasing ecumenicalism but they are bound by the objects of the charity: to preserve the fabric and grounds; to educate the public in the abbey's historic and religious importance; and to 'use 
Glastonbury Abbey to advance religion in accordance with the doctrines of the Church of England'. They have collaborated in research exploring multi-vocal perspectives on the abbey's archaeology (Smith 2013) and they have commissioned surveys to get a better sense of what motivates visitors to come to the abbey. All age groups are drawn by three themes especially - the abbey and its history, King Arthur and the spiritual connections of the abbey, notably the Arimathean legend (Gofton and McVerry 20I4). A new interpretation strategy was developed in $20 \mathrm{I} 2$ that stresses spirituality, both in the past and the present, together with the abbey's environmental resources (Bell and Smith 20I2). This is a distinctive approach in comparison with other monastic heritage sites, which often focus on the economic aspects of medieval monasteries as the first global corporations (see Chapter I). Glastonbury's interpretation strategy aims to develop compelling stories around the themes of spirit, space and society, including the abbey as a spiritual powerhouse and its place within the spiritual landscape; the changing use of space over time; and social themes of continuity, change and religious conflict. The emphasis on change, conflict and sacred space is unusual in the public interpretation of a monastic heritage site and reflects the abbey's close engagement with perspectives on monasticism informed by social archaeology (Gilchrist 2005).

For the first time, the abbey's spiritual value to other groups has been acknowledged in the interpretation strategy: 'spiritual stakeholders from different paths believe the abbey to be a sacred space and their beliefs should be respected' (Bell and Smith 20I2). The trust asks visitors to respect that Glastonbury Abbey is a Christian site: non-Christian rituals are prohibited but all spiritual contemplation is encouraged. There is growing experimentation with multi-vocality through temporary art exhibits and projects involving local artists, such as a joy tree in the grounds. However, the interpretation of the site remains strongly rooted in the concept of authenticity, based on archaeological evidence verified by experts. In outlining their values as a charity, the trustees of Glastonbury Abbey give first priority to 'authenticity and sense of place', alongside sustainability, education and community (Glastonbury Abbey Conservation Plan 2018). Authenticity continues to hold particular value at Glastonbury Abbey, as a site that has been at the centre of competing religious narratives for centuries (see Chapter 5). Authenticity is viewed as a deliberate strategy for negotiating the grey areas between 'fact and belief and maintaining a neutral middle ground between Christianity and alternative spiritualities (Bell and Smith 20I2).

\section{REPRESENTING LEGENDS: VISUAL RECONSTRUCTIONS} AND AUTHENTICITY

Glastonbury Abbey's interpretation strategy acknowledges that new approaches are needed to present the complex history and myths accessibly 
and to explore the relationship between legends and archaeological evidence. The abbey collaborated with the Universities of Reading and York to create digital reconstructions that tell the story of Glastonbury through the lens of archaeology, improving visitors' understanding of the spaces of the site, their chronological development and how they relate to the site's myths (www.glastonburyabbeyarchaeology.org). The reconstructions focus on the Anglo-Saxon churches, the Lady Chapel, the cloister, the abbot's complex and Arthur's tomb. Stuart Jeffrey has commented on the general challenge of engaging audiences with digital reconstructions, which by definition lack a sense of materiality, time-depth and spatial context (Jeffrey 20I5). He concludes that lack of authenticity is the central problem, which he defines in this context as a sense of aura, patina and proximity that is attached to material objects. The immaterial nature of digital reconstructions makes it difficult to feel a sense of ownership or connection with these images. They lack the tactile, material traces of 'age-value' that prompt emotional responses in the viewer (Holtorf 20I3a). Jeffrey calls for a more democratic approach to heritage visualisation, involving co-creation with local communities and a stronger emphasis on ${ }_{3} \mathrm{D}$ modelling and aesthetic values to increase the sense of visual authenticity.

The Glastonbury reconstructions involved co-creation with the abbey and were grounded in the aesthetics of medieval architecture. The abbey director stressed the importance of archaeological authenticity in developing the reconstructions: accurate, scaled models were generated from archaeological base recording; and lengthy discussions took place on every aspect of plan, form and materials. This level of archaeological detail added significant additional cost to the project, but the desire for archaeological authenticity overrode financial considerations. There are crucial aspects of Glastonbury's intangible heritage for which no archaeological evidence survives, notably the 'old church' associated with Joseph of Arimathea and King Arthur's tomb (see Chapter 5). These features are important in interpreting the site to the public and reconstructions were therefore requested by the abbey, to be based on descriptions in medieval documents. We took the decision to represent Arthur's tomb through the medium of a traditional artist's drawing (by Dominic Andrews), rather than a digital reconstruction. There is the risk of creating 'icons' when visualising intangible heritage and it is possible that digital reconstructions may be perceived as more objective than an artist's reconstruction. We used John Leland's description of the tomb from the I530s (Lindley 2007), archaeological evidence for the appearance of the church and comparative evidence of surviving ecclesiastical fittings from contemporary churches. We chose to represent a particular event in I33I, when the relics of Arthur and Guinevere were visited by King Edward III and Queen Philippa. The representation of a specific moment in history may help to counter the timeless effect that is typical of visualisations (see Figure 5.9). 
We also developed a digital reconstruction of the 'old church' associated with Joseph of Arimathea, based on the description by William of Malmesbury in II30, before the old church was destroyed by fire in II84 (see Chapter 5). There is a long tradition of visualisation associated with Joseph's church, beginning in I639 with Henry Spelman's Concilia. Spelman reconstructed the building with wattle walls and reed thatch, and a later phase with upright wooden planks (Figure 6.I9). His images conveyed an ideological purpose, emphasising the primitive simplicity of the structure, which served as a symbol of the early independence of the Anglican church, before the Roman mission to England (Stout 20I2: 256). Spelman's approach was connected to a wider tendency in seventeenth-century, Protestant scholarship that sought to demonstrate the early origins of indigenous British religion. For example, antiquaries such as William Stukeley promoted monuments like Stonehenge and Avebury as evidence for a Druidic religion that was the true precursor to the British church (Haycock 2002). Spelman's images may have influenced later archaeological reconstructions, notably one by Judith Dobie for a publication by Philip Rahtz and Lorna Watts, first published in I993 (Rahtz and Watts 2003: 95). Our reconstruction was influenced by archaeological knowledge of Anglo-Saxon domestic architecture and includes a nod to the features of early churches, such as double-splayed windows. The shape and ground-plan of the reconstruction are based on the surviving Lady Chapel, which was built on the site of the 'old church' in the IIgos. The only medieval depiction of the 'old church' is on a seal of Glastonbury Abbey dated II7I-8, showing the façade of a rectangular building with turrets similar to those of the later Lady Chapel (illustrated in Rahtz and Watts 2003: 96). We were conscious of the vernacular appearance of our reconstruction of Glastonbury's 'old church' but we were guided by medieval descriptions and influenced by earlier reconstructions (Figure 6.I8).

Before launching the new reconstructions to the public in 20I6, we trialled them at a workshop in Glastonbury involving representatives of diverse faith groups, including Anglican, Catholic, Quaker, Buddhist and New Age representatives. The reconstructions of the Anglo-Saxon churches, the medieval cloister, the Lady Chapel and the abbot's complex were all well received. Arthur's tomb prompted mixed responses, largely because people were surprised to see so much colour in the reconstruction, applied to both the fittings of the church and the tomb itself, which was described by Leland in the sixteenth century as 'black marble' (Lindley 2007: 150). However, responses to the reconstruction of the 'old church' surprised us: all participants at the workshop had expected to see a round church and they were shocked and disappointed by our reconstruction. We were initially perplexed by this response, but it soon became apparent that these faith groups were familiar with a different tradition of reconstruction of the 'old church'. Their 


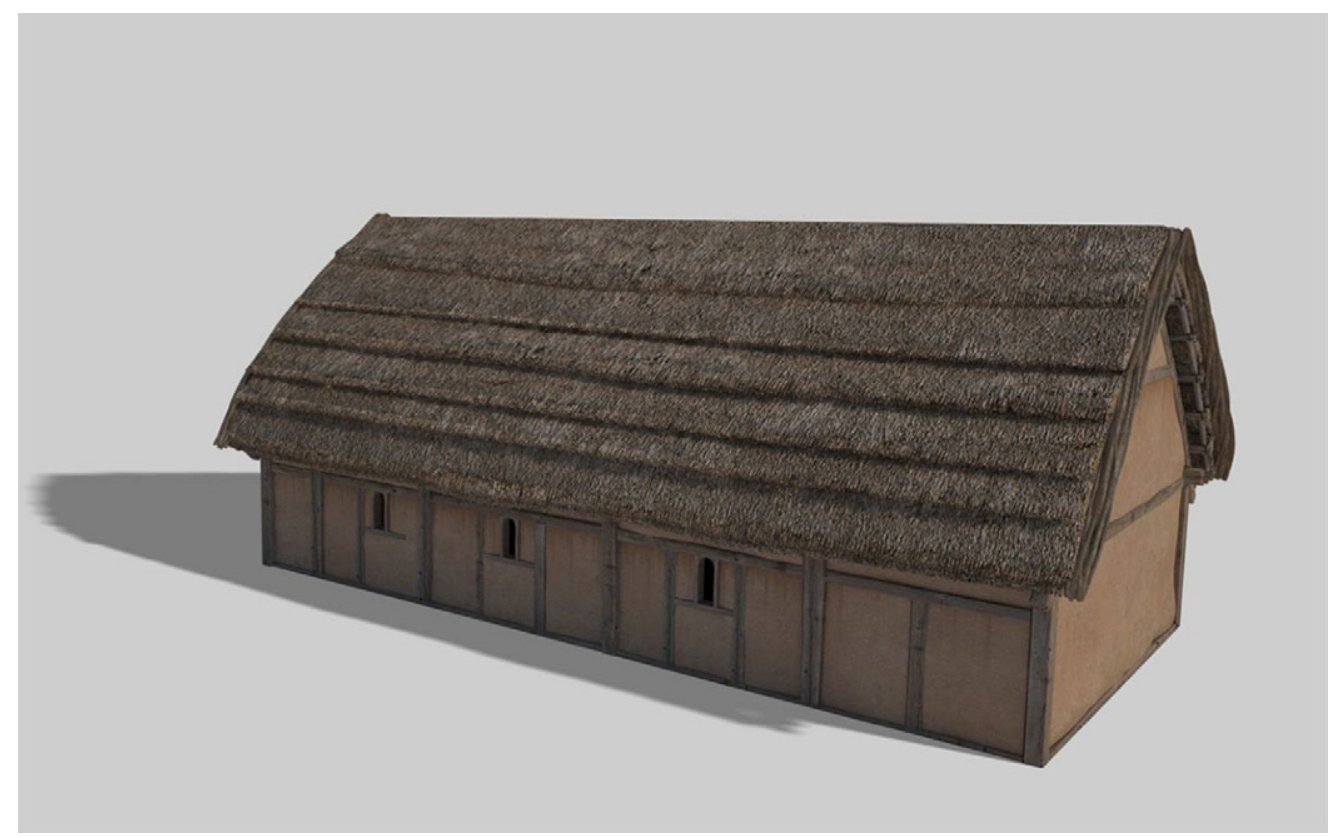

6. I 8 3D visualisation of the 'old church' at Glastonbury Abbey (Somerset). (C) The Centre for the Study of Christianity \& Culture, University of York

expectations were shaped by a reconstruction by Frederick Bligh Bond, dated to I939. Bond showed the 'old church' as a round structure at the centre of a palisaded compound, surrounded by twelve smaller round structures or cells (Figure 6.19).

Bond's image of Glastonbury in the first century CE was of an imagined early British monastery, following the form of an Iron Age village, and showing the apostolic number of twelve cells. He was clearly affected by the excavations at Glastonbury Lake Village, an Iron Age village constructed on a crannog in the Somerset Levels, $5 \mathrm{~km}$ northwest of Glastonbury. The Lake Village was excavated from 1892 to 1907 and Bond was closely familiar with the excavators and their findings (Bulleid et al. I9I7). His reconstruction was evidently influenced by the paintings of the Glastonbury Lake Village by the artist Amédée Forestier, completed for the Illustrated London News (I9II) (Figure 6.20). Bond depicted a round enclosure, consistent with both the Irish monastic tradition and with Forestier's representation of Glastonbury Lake Village. By representing Joseph's church at the centre of an Iron Age village, Bond emphasised the British origins of the early church at Glastonbury and its continuity with ancient traditions that pre-dated the Anglo-Saxon monastery. His image of the early church has been widely reproduced in New Age literature and has become the local symbol of the church reputedly founded by Joseph of Arimathea. 

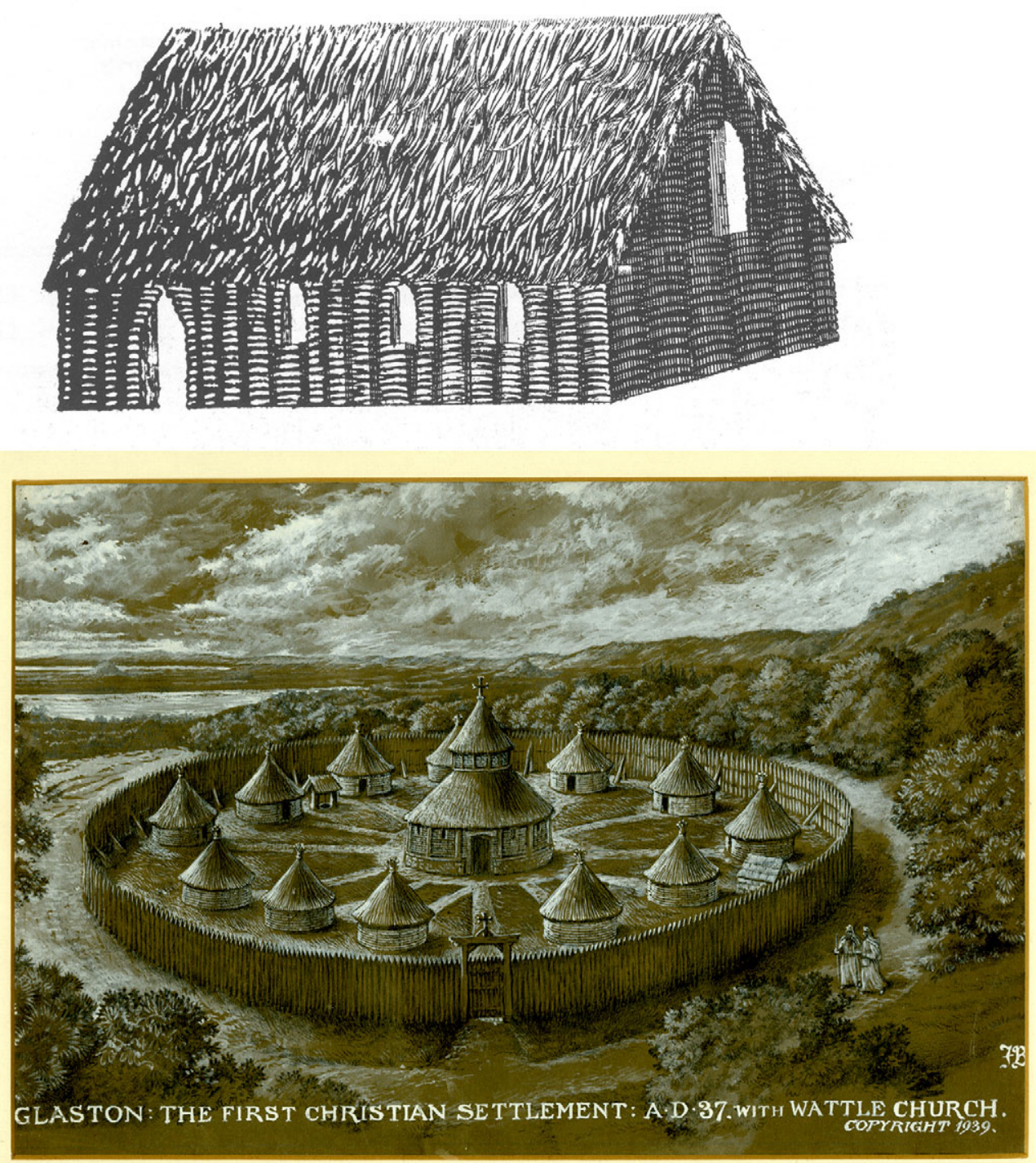

6. I9 Reconstructions of Glastonbury's 'old church': by Spelman (I639) (above) and Bligh Bond (I939). Reproduced by kind permission of Glastonbury Abbey

The challenge of reconstructing Glastonbury's 'old church' highlights the complexity of authenticity, which can be informed by competing forms of knowledge and value, in this case archaeological scholarship versus local faith traditions of knowledge. It also illustrates the difficulties involved in democratising heritage visualisations when multiple communities and narratives are involved. Our reconstruction was based on co-creation, but with the abbey as the key stakeholder, an institution which places maximum value on archaeological authenticity. It was only through engagement with the wider 


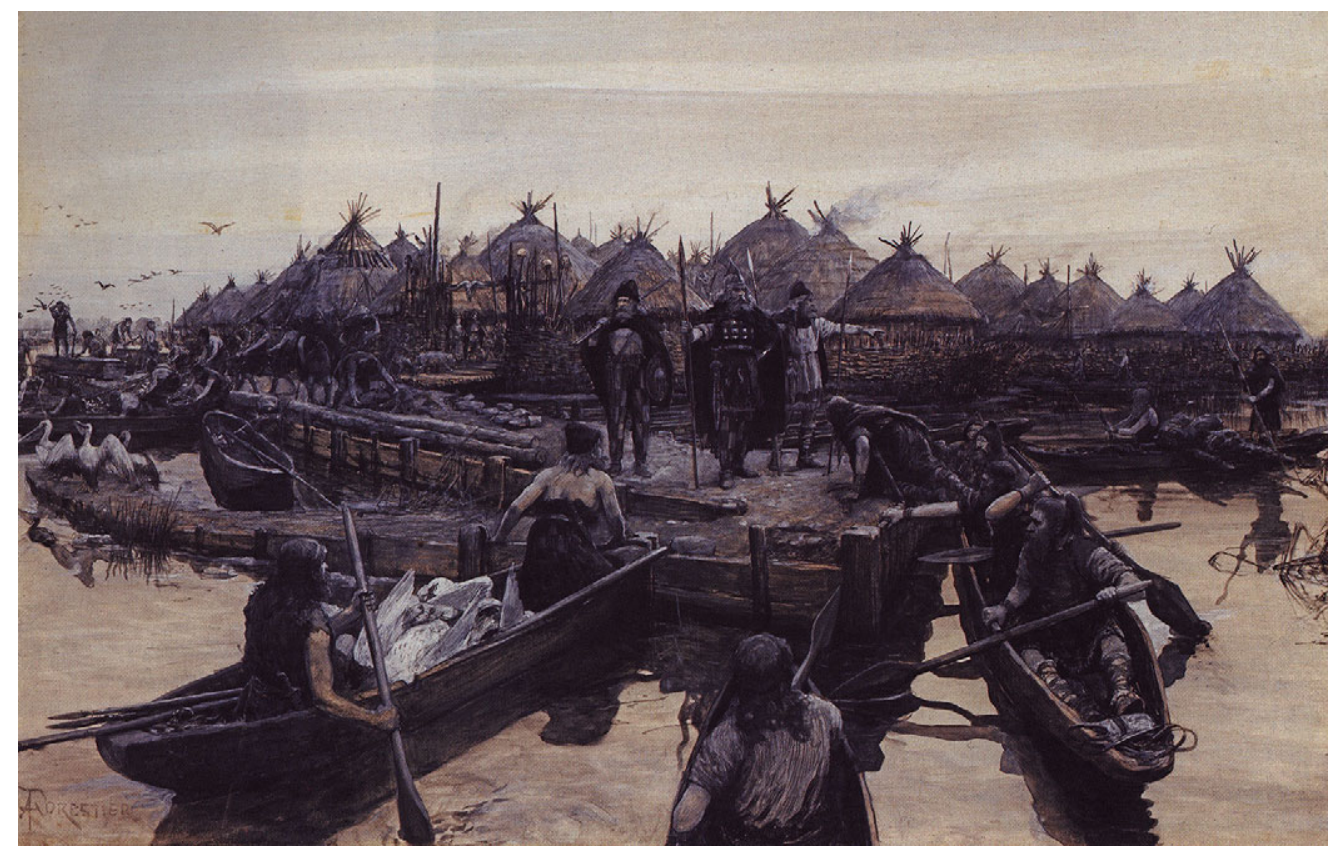

6.20 Artist reconstruction of Glastonbury Lake Village by Forestier (I9II). Public Domain

community of spiritual groups that we became aware of the tensions and sensitivities around this reconstruction. Their response made it clear that the principle of multi-vocality (Hodder 2008) was essential in representing the 'old church' associated with Joseph of Arimathea. It also highlighted longstanding themes in the visual representation of Joseph's church and the spiritual significance of choosing to place it either within an Iron Age (Celtic) or an AngloSaxon building tradition. We concluded that no single image could convey the conflicting traditions of knowledge and representation that are associated with Glastonbury's 'old church'. We took the decision to reproduce Bond's image alongside our reconstruction: they are shown together in both the new printed guidebook of Glastonbury Abbey and digital resources on site, in an effort to convey the ambiguities and subjectivities involved in the research process that underpins visual reconstruction (Gilchrist et al. 20I7: 29; www.glastonburyab beyarchaeology.org).

\section{CONCLUSIONS: 'DEEP TIME' AND 'THIN PLACES'}

Archaeologists have long debated the role of material evidence in supporting nationalist narratives and they have appraised the meanings of authenticity in different social and cultural contexts. And yet, there has been virtually no critical reflection on how archaeology has been used to authenticate religious narratives at medieval sacred sites. This is in stark contrast with the extensive 
archaeological analysis of pagan engagement with prehistoric sacred sites such as Çatalhöyük (Hodder 1998). The archaeological study of medieval Christianity has remained largely outside social, political and heritage discourses (see Chapter I). As recently as the I950s and I960s, archaeologists perpetuated myths at sacred sites to valorise 'Golden Age' stories, by seeking to demonstrate the saintly origins of sites such as Glastonbury and Whithorn. The archaeology was forced to fit a mythological framework, causing misrepresentation of evidence and leading to major delays in publication. These sites eventually reached publication decades after their excavation, achieved through scientific analysis and rejection of preconceived ideas about site origins (Gilchrist and Green 20I5; Lowe 2009).

Heritage practice has recently shifted towards more democratic principles that challenge the pillars of academic archaeology: social value is increasingly regarded as more significant than the principles of antiquity, fabric and authenticity (Emerick 20I4). However, these traditional designations remain important at sacred sites, where the authentication of early origins and the survival of original fabric are crucial in validating the unique sense of place and the numinous. Tangible and intangible heritage are brought together at sacred sites: authenticity represents a strategy for people to negotiate their own spiritual beliefs in relation to sacred landscapes, buildings, spaces and objects. The case studies discussed here illustrate how faith groups draw on archaeology selectively, both to authenticate their own versions of the past and to compete with alternative spiritual narratives. At Walsingham, for example, the Anglican Holy House built in the I930s incorporated worked stone from medieval monastic sites, to rival the authentic medieval chapel that was the focus of the Catholic shrine (Coleman 2004). Replication was used at Walsingham and Iona in the twentieth century to reconstruct the authority of medievalism. The architectural reuse and replication of medieval fabric were strategies adopted to achieve 'age-value', a perceptible quality of 'pastness' that signals authenticity, regardless of age (Holtorf 20I3a). In contrast, Glastonbury Abbey pared back interpretation of the ruins to minimal presentation based on professional judgements of archaeological authenticity. Through their involvement with the controversial figure of Frederick Bligh Bond, the trustees learned an early lesson in how archaeology can be appropriated to serve alternative narratives. The abbey's engagement with the heritage pioneer Charles Peers had a more lasting impact on the interpretation of the site: Glastonbury came to embody the national 'preservation ethic' that presented medieval abbeys as 'dead' monuments 'frozen' in time (Emerick 20I4: 83).

Glastonbury Abbey demonstrates that a medieval monastic ruin can be a highly contested heritage site, with similar conflicts over access to sacred space and freedom to perform rituals that characterise UNESCO World Heritage Sites such as Great Zimbabwe and Stonehenge (Fontein 2006; Wallis and Blain 
2003). Authenticity based on quality of evidence remains an important strategy for Glastonbury Abbey in mediating between 'fact and belief' (Bell and Smith 20I2), a means of negotiating an interpretative position for an Anglican site immersed in legends and which serves as a beacon for New Age spirituality. As a heritage site, the abbey has been highly conservative in relation to its myths, wary of commemorating Arthur's tomb or the church of Joseph of Arimathea. This is now changing, with a more ecumenical approach that encourages spiritual reflection and creative engagement with the abbey's legends. Archaeological authenticity will remain a core value for the abbey - because an emphasis on scholarship and empirical evidence sets the abbey apart from alternative religious narratives at Glastonbury.

Marion Bowman argues that the Glastonbury landscape is the key spiritual focus for the Community of Avalon: New Age seekers are drawn to striking natural features such as the Tor with its contoured hill, the chalybeate spring of Chalice Well and the miraculous Holy Thorn that flowers twice a year (Bowman 2009). This strong attachment to landscape and the natural environment is more broadly characteristic of Celtic and pagan spirituality (Power 2006). However, I would argue that New Age interest in Glastonbury is equally concerned with 'Golden Age' stories that lend a sense of deep time, ranging from Arthur and Joseph of Arimathea, to the alleged Druidic university and prehistoric goddess cult. The Community of Avalon is not concerned with the archaeological authenticity of these stories, but they value the antiquity and materiality of Glastonbury, alongside its special qualities as a healing landscape and a 'thin place', where the physical and spiritual realms meet. Catholic pilgrimage to Glastonbury has also begun to focus on the abbey's long history as a Marian shrine and place of healing, in contrast with the twentieth-century Catholic veneration of Glastonbury as the site of Abbot Whiting's martyrdom at the Dissolution (Bowman 2009: I65).

I will conclude this discussion with a personal story about myth and authenticity. When the monograph reporting the new research on Glastonbury Abbey was published in late 20I5 (Gilchrist and Green 20I5), there was substantial national and international media interest. The tone of the coverage was largely set by the first article that appeared in The Guardian newspaper: an archaeological study 'has comprehensively demolished cherished myths about one of the most romantic religious sites in England' (Kennedy 20I5). The article assumed that because I had challenged Radford's archaeological evidence for Arthur's grave (discussed above), my aim was to discredit the whole fabric of legends surrounding Glastonbury. Archaeology was characterised as 'myth-busting' science triumphing over outmoded religion. I was taken aback by this reaction, because I had under-estimated the cultural value that had been placed on Radford's evidential claims. In the early I960s, a highly respected archaeologist announced that he had found material proof for the exhumation 
in II9I of the legendary Arthur and Guinevere at Glastonbury. This news was heralded by the national press as 'one of the greatest archaeological finds of the century' with the story of Radford's quest described as 'almost as romantic as the very picture-book stories of Arthur himself (The Evening News, 3I August, I962). The discovery of the alleged exhumation site in I963 drew crowds of tourists and boosted the local economy: visitors claimed that they had 'seen the grave of King Arthur in Avalon' (The Times, I8 August 1963). Radford's claim to have authenticated Arthur's grave had itself become part of Glastonbury's intangible heritage. My critical reading of his archaeological evidence was therefore perceived as undermining the authenticity of the whole Arthur story - a myth of nationhood that people want to believe.

I was concerned about how the Glastonbury community would respond to the media coverage and its representation of my research. The abbey was initially worried, given the high value that they place on authenticity based on professional judgement of archaeological evidence. However, they soon regarded the media storm as another compelling Glastonbury story - evidence of the enduring power of the myths of Arthur and Arimathea. The (New Age) Community of Avalon was interested to hear new archaeological findings but their personal beliefs about Glastonbury were not challenged. For them, there is no single truth about Glastonbury; its sacred quality lies in the personal, embodied experience of the place (Bowman 2000). For me, this was a lesson in the cultural relativism of authenticity even within a single locale, a small town of less than I0,000 people. Authenticity is a slippery concept in a place with five different Holy Thorn trees believed to descend from the staff of Joseph of Arimathea, and where archaeology has been actively used since the twelfth century to authenticate myths of the 'Golden Age' (see Chapter 5).

Glastonbury's contested heritage has shown me that authenticity is certainly not 'dead' (Emerick 20I4: 7). Rather than pronounce its demise, we need to develop more fluid understandings of authenticity in relation to 'living heritage' (Holtorf 20I3b; Jones 20I0). For faith communities, principles of authenticity can serve as both 'neutral middle ground' and as confirmation of the spiritual credentials of a place, through nuanced understanding of its materiality and historicity. A deep time perspective demonstrates the layered and multivalent qualities of sacred heritage, changing meanings over time and between faith communities (see Chapter I). The materiality of archaeology underpins these concepts of authenticity - the enduring quality of tangible heritage and its ability to connect the past with the present through entangled social relationships (Fowler and Harris 20I5). In sacred landscapes such as Glastonbury, the material remains of the past enhance the effect of spiritual enchantment; authenticity becomes 'a way of expressing religious longing in a secularised world' (Fredengren 20I6: 493). The living heritage approach has been criticised for its presentist framework, which prioritises the value of heritage as 
defined by contemporary communities and individuals. Critical appraisal of sacred heritage demonstrates that contemporary perceptions of value are also connected to the materiality of archaeology, its durability in connecting present place with the deep past.

We must also be more alert to the risks of relativism that come with the 'democratic turn' in heritage studies. Heritage can be appropriated to serve instrumentalist political agendas, in other words, using the past in attempts to solve contemporary social challenges (Swedish National Heritage Board 20I6a). European heritage agencies have stepped up their attention to the relationship between contemporary social identity, social cohesion and national heritage. For example, Historic England has pledged 'to promote the past in a way that is inclusive to all and that celebrates the cultural diversity of England's heritage' (Historic England 20I6: 8), while Historic Environment Scotland asserts the value of archaeology to 'help everyone celebrate the diversity of our heritage, regardless of their race, religion, gender or ability, and tell stories that reach beyond our borders, such as trade and migration' (Historic Environment Scotland 20I6: 5). In Sweden, the Heritage Board has consciously stepped back from identity politics and has instead committed to more collaborative processes of heritage management through new models of participation and co-creation (Swedish Heritage Board 20I6b). At the same time that heritage agencies are promoting social inclusion and collaboration, right-wing political parties aim to harness the power of heritage for exclusionary political agendas (Niklasson and Hølleland 2018: 139). The relativism of the living heritage approach provides no means of choosing between versions of the past and how they are used in the present.

Is it possible to achieve a balance between the democratisation of heritage and the interpretation of empirical archaeology, that is, social value on one hand (constructivist approaches), versus evidential value on the other (materialist approaches)? Critical reflection on different contemporary values and relative meanings of the past is one possible route of navigation through this complexity (Jones 20I7; Jones and Leech 2015). An alternative is to consider the value of heritage sites in terms of their materiality, the power of archaeology to connect the present with the deep past and to provoke emotional and spiritual experiences (Fredengren 20I6). Archaeology brings its own value to sacred heritage: the material study of religion is a distinctive contribution to understanding people's experience in the past - how bodies, things and spaces engaged to construct the sensory qualities of medieval religion. Focus on the material and sensory dimensions may help to make the past more accessible, opening up opportunities for people today to experience sacred sites and material culture and to draw their own meanings from them. This relational approach is relevant to both humanist and spiritual engagements with sacred sites, intersecting with social memory, an appreciation of landscapes, the 
aesthetics of architecture, personal well-being and individual reflections on the numinous, mortality and loss. The 'spiritual' value of heritage is part of a more holistic perception of religious sites and landscapes - one that is not exclusive to faith communities (see Chapter I). We should be confident in crafting interpretations that are firmly rooted in archaeological evidence and also appeal to the strong contemporary desire to know more about spiritual beliefs in the past. This book began by commenting on the intellectual distance between heritage theory, heritage management and medieval archaeology. These separate fields can be drawn together in approaches that seek to be relevant and inclusive and at the same time are grounded in fresh interpretative perspectives on archaeological evidence. By reflecting more critically on spiritual beliefs in our interpretations, we may encourage deeper public engagement with sacred heritage and contribute greater sustainability to medieval archaeology. 
